\title{
A Search for a Method to Improve Critical Thinking Skills in Social Studies Teaching: Writing-to-Learn*
}

\author{
Fatih KAYAALP1 \\ Zonguldak Bülent Ecevit University \\ Zonguldak, TURKEY
}

\author{
Elif MERAL2 \\ Atatürk University \\ Erzurum, TURKEY \\ İbrahim Fevzi ŞAHİN 4 \\ Atatürk University, Erzurum, TURKEY
}

\author{
Ufuk ŞİMŞEK ${ }^{3}$ \\ Atatürk University \\ Erzurum, TURKEY
}

\begin{abstract}
*This study was presented as an abstract paper in 8th International Symposium on Social Studies Education, 7-9 November 2019, Ankara, Turkey ${ }^{1}$ Dr., Department of Turkish and Social Sciences Education, Zonguldak Bülent Ecevit University, Zonguldak, Turkey, fatihkayaalp25 [at] gmail.com, ORCID: 0000-0001-7640-5045

${ }^{2}$ Corresponding author: Assist Prof. Dr., Department of Turkish and Social Sciences Education, Atatürk University, Erzurum, Turkey, elif.meral [at] atauni.edu.tr , ORCID: 0000-0002-2560-0120

3Prof. Dr., Department of Turkish and Social Sciences Education, Atatürk University, Erzurum, Turkey, ufuk [at] atauni.edu.tr , 0RCID: 0000-0002-4699-0674 ${ }^{4}$ Prof. Dr., Department of Turkish and Social Sciences Education, Atatürk University, Erzurum, Turkey, ifevzi [at] atauni.edu.tr , ORCID: 0000-0003-2566-4623
\end{abstract}

\begin{abstract}
The aim of this study is to investigate the effects of using multiple writing-to-learn activities on the critical thinking skills and dispositions of prospective teachers. For this purpose, the current study employed an embedded mixedmethods design and was carried out with 34 prospective Social Studies teachers who are studying at a public university. Research data were collected with the California Critical Thinking Disposition Inventory, as well as using the Holistic Critical Thinking Scoring Rubric, and also, semi-structured interview forms. In the research process, a variety of writing activities such as letters, diaries, columns and news articles were used for learning purposes. The quantitative data obtained in the research were analyzed descriptively and predictively, while the qualitative data were subjected to content analysis. The results of the study revealed that the writing-to learn activities led the prospective Social Studies teachers to do research, use evidence, get to know different ideas, and evaluate what they learned in a holistic way. Such a situation made a significant difference on the critical thinking skills and critical thinking dispositions of the prospective Social Studies teachers. Given such a result, it is recommended to draw upon writing-to-learn activities in order to develop different courses, subjects and higher-order thinking skills.
\end{abstract}

\section{Keywords}

Critical Thinking, Social Studies, Writing-to-Learn

To cite this article: Kayaalp, F., Meral, E., Şimșek, U. \& Şahin, İ. F. (2020). A Search for a Method to Improve Critical Thinking Skills in Social Studies Teaching: Writing-to-Learn. Review of International Geographical Education (RIGEO), 10(3), 400-430. Retrieved from http://www.rigeo.org/vol10no3/Number3Summer/RIGEO-V10-N3-7.pdf. . doi: 10.33403rigeo.719222 
Changes in social life lead to the occurrence of an indispensable transformation process. Classrooms or teaching environments, which are central to social transformations, are where the process of information exchange and transformation are deeply felt. Today, they are felt to such an extent that information-based teaching environments puts an emphasis on different ways of obtaining information. In the past, a significant value was attributed to the amount of information obtained in a classroom and the way in which such information was transferred to others; while today, it is the methods of acquiring information that are considered to be more valuable. In today's teaching environments, students are expected to possess the necessary skills to create a new product by generating new information from existing data, transforming it, and adding to what they have already acquired, rather than being just a carrier of information. This criterion of qualification that students are to achieve has brought up many higher-order ways of thinking to support students in the process of transforming information. One of these higher-order ways of thinking is critical thinking.

Critical thinking is expressed as reasoning-based and decision-oriented thinking process to know about and act on a topic (Ennis, 1993); it is a process of making decisions after testing the assertions and arguments made based on research or a search process (Ruggiero, 2017). This critical evaluation and decision-making process requires specific planning and organization about a problem to actively use cognitive skills, act independently of prejudices, be open to different thoughts, consider the evidence and reasons put forward to support an idea, and explain them as a whole (Özden, 2014; Şahinel, 2015). While making this plan and organization, skills, for critical thinking must to be acquired, skills such as analysis, inference, reasoning, induction and deduction must occur in addition to evaluation as stated by Facione (1990). Considering such a requirement, it is necessary to create appropriate learning environments so that critical thinking can be promoted.

Emphasized as a unique way of learning (Emig, 1977), writing-to-learn has been involved in teaching processes as an alternative learning model since 1970s with the feature of providing a learning environment that will contribute to the development of critical thinking. Being the focal point of learning-oriented activities, writing-to-learn enables students to learn the subject matter comprehensively by emphasizing the importance of research ability (Reilly, 2007) involved in critical thinking (Ashworth, 1992; Cantrell, Fusaro \& Dougherty, 2000; Kingir, 2013; Köksal, 2019; Noel, 1996; Nurnberg, 2017; Pınar, 2019; Poock, Burke, Greenbowe \& Hand, 2007; Tarchichi, 2016; Yasul, 2019; Yllmaz, 2017). In this comprehensive learning process, writing-to-learn activities directly affects skills and qualities, such as the active use of different ways of thinking (Hohenshell \& Hand, 2006), problem-basedlearning (Chappell, 2006, Hensberry \& Jacobbe, 2012), activating prior knowledge (Bozkurt, 2017; Putti, 2011), using evidence (Sielaff \& Washburn, 2015), and interpreting (Külekçi, 2018). Each skill and quality contribute to the development of critical thinking in many different ways. With the multi-dimensional effects of writing-to-learn activities, students can combine processes such as decisionmaking, imagining, questioning, and organizing information (Demirbağ, 2011). Students are able to devise a new perspective based on discovery against an existing problem, or solve a problem they face (Flower \& Hayes, 1981) through critical 
thinking processes. In such processes, writing-to-learn provides important opportunities for students to construct and transform information (Tynjala, 1998) by acting as a bridge between new information and prior knowledge because the writing-to-learn process helps students to develop explanations (Keys, Hand, Prain \& Collins, 1999).

When considered together, writing-to-learn and critical thinking indicate a similarity between their structural features. Figure 1 presents the image of the similarity between critical thinking and writing-to-learn model.

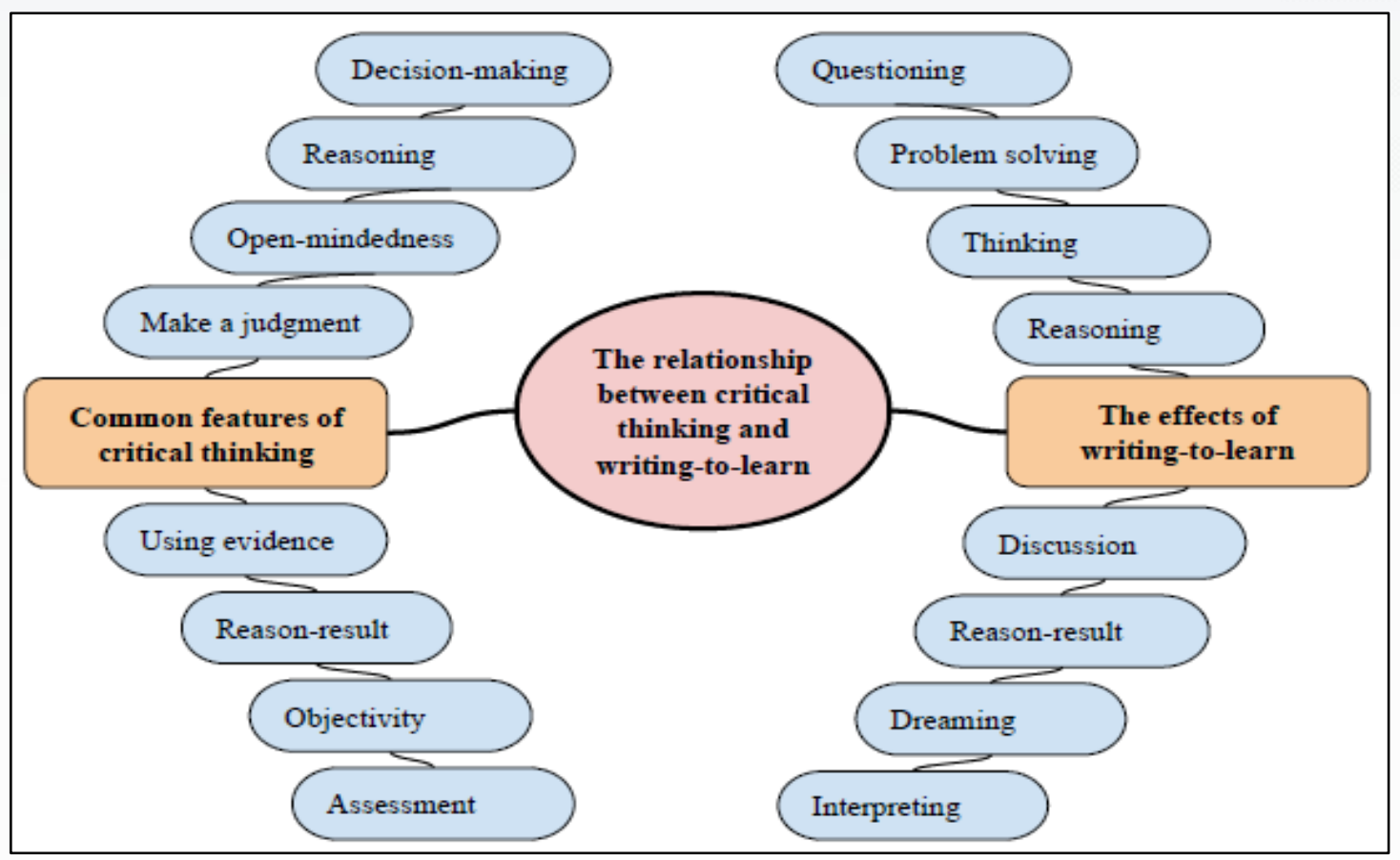

Figure 1. The relationship between critical thinking and writing-to-learn model.

Examining the studies about writing-to-learn, Rivard (1994) pointed out there is insufficient interest in the use of writing-to-learn in developing critical thinking skills. However, in the years that followed, many researchers realized the structural relationship between critical thinking skills and writing-to-learn activities so they sought to develop critical thinking skills through the writing-to-learn activities. From a study of the literature, Sinaga and Feraine (2017) aimed to develop students' critical thinking skills through non-traditional types of writing, and it was revealed that the critical thinking skills of the students in the experimental group, where nontraditional types of writing were applied, showed a significant change compared to those in the control group. By making use of writing-to-learn activities in the development of critical thinking skills, Öz (2015) stated that writing-to-learn activities enabled the development of reasoning and reflective thinking skills, and created a significant difference in the development of students' academic success, scientific processing skills as well as critical thinking skills. In another study focusing on students' critical thinking in the learning process, Quitadamo and Kurtz (2007) examined the role of writing in the development of students' critical thinking skills. Quitadamo and Kurtz (2007) stated that an improvement in the skills of inference and analysis occurred amongst students in the research group using 
writing activities and the writing activities had positive effects on the development of their critical thinking skills. In the development of critical thinking skills, Daşdemir (2017) used different types of writing-to-learn activities, such as letter writing; Uzoğlu (2014) used diary and letter writing, while Gupta, Burke, Mehta, and Greenbowe (2015) addressed the effects of the Science Writing Heuristic (SWH) approach on students' critical thinking skills. Comparing the SWH with traditional types of writing, Gupta et al., (2015) concluded that the SWH made a significant difference on the development of critical thinking skills, and pointed out the impact of SWH processes such as organization, explanation, and evaluation on the structuring of cognitive knowledge. Similarly to Gupta et al., (2015), Stephenson and Sadler-McKnight (2016) studied the effects of SWH on students 'critical thinking skills, and compared traditional writing with SWH and found out that in contrast to traditional writing, writing with SWH was more effective on developing students' critical thinking skills. Hooey and Bailey (2005) gave students an opportunity to experience a subject through writing-to-learn: in teaching geographical subjects and skills, Hooey and Bailey (2005) asserted that writing-to-learn provides a significant improvement in students' geographic and critical thinking skills besides enabling them to learn the subjects and concepts related to a specific topic. It was even emphasized that many students found the process of writing-to-learn to be valuable.

It is observed that studies seeking to develop critical thinking skills through writing-to-learn activities are mainly conducted in the fields of Biology, (Butler, 1990; Erkan, 2008; Quitadamo \& Kurtz, 2007) Chemistry (Burhanuddin \& Ibrahim, 2019; Gupta et al., 2015; Stephenson \& Sadler-McKnight, 2016; Vanorden, 1987), Life Sciences (Öz, 2015), Physics (Daşdemir, 2017; Sinaga \& Feraine, 2017), Geography (Hooey \& Bailey, 2005), Language teaching (Nejmaoui, 2019), Science education (Uzoğlu, 2014) and Social Studies (Giroux, 1978). Such studies in the literature show that the use of writing-to-learn activities for the development of critical thinking skills is often concentrated in the field of Life Sciences, and is insufficiently used in Social Sciences and the teaching of Social Studies, which is the anthology of Social Sciences.

Social Studies, which is the study of people (Zarrillo, 2016), integrates information and methods from the Social Sciences discipline and includes critical thinking in a program for teaching processes (National Council for The Social Studies [NCSS], 1994; Ministry of National Education [MoNE], 2018). Besides searching for various ways and methods to develop critical thinking skills within the Social Studies curriculum the Social Studies program makes decisions based on information, solves problems and seeks to raise effective citizens in changing country and world conditions (Öztürk, 2015, p. 4), The relevant literature reveals there are efforts to develop critical thinking skills through various teaching methods and techniques at different grade levels. The studies have examined the impact on the development of critical thinking skills pertaining to practice in Social Studies classes such as reading graphs (Clark, 1977), questioning for learning model (AlKhayyatt, 1980), using cartoons (Köseoğlu, 2009), implementing a research-based learning approach (Çalışkan, 2009), investigating current events (Gürdoğan-Bayır, 2010; Yücel \& Köçer 2019), going on expeditions (Açar, 2010), interpreting maps (Boucher, 2010), and using a case study method (İbrahimoğlu \& Öztürk, 2013), or 
game-based learning (Cicchino, 2013) or interactive mobile devices (Lin, Widdall \& Ward, 2014), or digital stories (Ünlü, 2018), or an argumentation-based teaching approach (Meral, 2018), or Socratic inquiry-based learning method (Allen, 2018), or problem-based learning (Anisaroh, Roesminingsih \& Suyanto, 2018; Shepherd, 1998) or questioning the history of cooperative learning (Frusci, 2019), or authentic learning practices (Baştürk, 2019).

An analysis of literature from the past to present shows the use of different methods for developing critical thinking in Social Studies courses (including collaborative and individual learning methods) together with efforts to integrate technology into learning environments indicate a favourable development in the teaching of critical thinking skills. However, the pertinent studies have generally been conducted on the dimension of disposition as developed by Facione (1990). Such studies indicate that critical thinking "includes some skills and dispositions", and have mostly followed a result-oriented evaluation process, expressing a deficient aspect in the development of critical thinking. In the current study, it is thought that disposition, which is described as one's willingness to think critically, and critical thinking skills (Zhang, 2003), which is the effort to be able to think in the face of a problem, can be developed with writing-to-learn activities. In this research, two dimensions of critical thinking - dispositions and skills - were developed through writing-to-learn activities. The differences in dispositions were evaluated with a critical thinking scale, while the development in critical thinking skills were followed up through a critical thinking rubric. The fact that this research focused on both dispositions and skills as the dimensions of critical thinking makes the scope of research broader and differentiates it from other studies. Another strength of this research is that the study was carried out on both the process and the result. The participants were evaluated with regard to their improvement by giving them feedback based on the activities performed in the process. Other strengths are that multiple writing-to-learn activities (diaries, columns, news articles) were developed in the study in order to keep the interest and attention of the participants alive. The research included prospective teachers of Social Studies who would directly take part in the teaching of critical thinking. In addition, both the lack of similar studies in Social Studies teaching and the insufficient number of studies about the development of critical thinking through writing-to-learn activities indicate the importance of this study. It is thought that this study will contribute to the literature and give a different perspective to the development of critical thinking. Accordingly, the aim of this study is to examine the effects of using writing-to-learn activities in developing the skills of critical thinking. Depending on this general purpose, answers to the following research questions were sought:

- To what extent are the use of writing-to-learn activities effective on developing the critical thinking levels of prospective Social Studies teachers?

- Do the use of writing-to-learn activities have a significant impact on the disposition dimension of critical thinking amongst prospective Social Studies teachers?

- What are the opinions of the prospective Social Studies teachers about the use of writing-to-learn activities in the development of critical thinking skills? 


\section{Methodology}

\section{Research Design}

A mixed-methods approach was used for this research. A mixed-method design provides an opportunity to develop a better understanding of the research problem due to using both quantitative and qualitative approaches (Creswell, 2012). It is noteworthy that mixed-method approaches are classified in different ways by different researchers in the literature. This study employed the embedded design from among the classification factors, namely triangulation, embedded, explanatory and exploratory designs introduced by Creswell and Plano-Clark (2007). In the embedded design, qualitative data are included in a predominantly quantitative study, or quantitative data are included in a predominantly qualitative study as supporting data (Creswell \& Plano-Clark 2007; Creswell, 2009; Creswell, 2012). Qualitative data were used to support the quantitative data within this predominantly quantitative data-based study. A single group pre-test and post-test experimental design, one of the quantitative research approaches, was used in the quantitative dimension of the research designed according to the embedded method (McMillan \& Schumacher, 2014). In the qualitative dimension of the research, semistructured interviews were conducted with 10 prospective teachers in the study group in order to support the quantitative data with qualitative data.

\section{Study Group}

The study group is composed of 34 teachers studying at the 4th Grade at the School of Social Studies Teaching during the academic year of 2018-2019 at a public university in the West Black Sea region in Turkey. Table 1 shows the demographic data of the study group.

Table 1

Distribution of Demographic Data of the Study Group

\begin{tabular}{lll}
\hline Gender & Frequency & Percentage (\%) \\
\hline Male & 16 & 47.05 \\
Female & 18 & 52.95 \\
\hline Total & 34 & 100 \\
\hline
\end{tabular}

\section{Data Collection Tools}

The California Critical Thinking Disposition Inventory (CCTDI). The California Critical Thinking Disposition Inventory (CCTDI) was used to measure the critical thinking dispositions of prospective teachers. Adapted into Turkish by Kökdemir (2003) after a validity and reliability study, this inventory consists of 51 items and 6 subscales, which are Analyticity (10 items), Open-mindedness (12 items), Inquisitiveness ( 9 items), Self-Confidence ( 7 items), Truth-seeking ( 7 items), and Systematicity (6 items). Each item was rated on a 6-point Likert-type scale ranging from "strongly disagree" to "strongly agree", including strongly disagree (1 point), disagree ( 2 points), partially disagree ( 3 points), partially agree (4 points), agree ( 5 points), and strongly agree ( 5 points). The internal consistency coefficient was .75 for the analyticity subscale, .75 for the open-mindedness subscale, .78 for the inquisitiveness subscale, .77 for the self-confidence subscale, .61 for the truthseeking subscale, and .63 for the systematicity subscale, while the internal 
consistency coefficient for the overall scale was calculated as .88. The internal consistency reliability coefficient of the CCTDI for this study (Cronbach's alpha) was calculated as .91.

The Holistic Critical Thinking Scoring Rubric. In the research process, multiple writing-to-learn activities (letters, news articles, columns, diaries) were prepared and used by the researcher. The Holistic Critical Thinking Scoring Rubric developed by Facione and Facione (1994) was used to evaluate the writing activities created by the prospective teachers. The rubric developed by Facione and Facione (1994) is rated as "Weak, Unacceptable, Acceptable, and Strong". In the study, the rubric developed by Facione and Facione (1994), which is used to facilitate the evaluation of prospective teachers' critical thinking skills, was arranged by researchers as Level 1 (Weak), Level 2 (Unacceptable), Level 3 (Acceptable), and Level 4 (Strong). The components and levels that form the critical thinking scoring rubric for determining the levels developed by Facione and Facione (1994) are presented in Table 2 in detail.

Table 2

The Holistic Critical Thinking Scoring Rubric Level and Its Components

\begin{tabular}{ll}
\hline Levels of Critical Thinking & Components \\
\hline \multirow{2}{*}{ Level 1 (Weak) } & $\begin{array}{l}\text { Biased, thinks superficially, defends false claims, incapable of } \\
\text { establishing a cause-effect relationship, incapable of using } \\
\text { evidence, closed to different ideas. }\end{array}$ \\
\hline Level 2 (Unacceptable) & $\begin{array}{l}\text { Misinterprets the problems, inadequate to put forward strong } \\
\text { reasons, ignoring alternative ideas, incapable of making objective } \\
\text { evaluations, evaluating without any evidence, and retains } \\
\text { prejudice. }\end{array}$ \\
\hline Level 3 (Acceptable) & $\begin{array}{l}\text { Defines the problem correctly, explains the claims and } \\
\text { justifications related to the subject, accepts different ideas, and } \\
\text { tries to reach correct results. }\end{array}$ \\
\hline & $\begin{array}{l}\text { Defines the problem correctly, explains the claims and } \\
\text { justifications related to the subject, evaluates different ideas as a } \\
\text { whole, reaches definite and logical results, makes accurate and } \\
\text { unbiased evaluations. }\end{array}$ \\
\hline
\end{tabular}

Semi-Structured Interview Form. In the research, a semi-structured interview form was used to support quantitative data and to evaluate prospective teachers' views on the application. The interviews were conducted with 10 prospective teachers in the application group selected by the maximum variation sampling method. The interviews were recorded with a voice recorder with the permission of the students. Students were informed that their identity information will be kept confidential and their names will be used by coding (PT/1, PT/2, PT/3, PT/4,... $\mathrm{PT} / 10)$.

\section{The Application Process}

The research was carried out for 6 weeks in practice in the "Today's World Problems" course contained in the fourth-grade curriculum of the Social Studies teaching during the academic year of 2018-2019. The application process of the research is presented in Table 3 in detail.

Table 3 
Kayaalp, F., Meral, E., SSimșek, U., Sahin, I. F. (2020). A Search for a Method to Improve Critical....

The Research Application Process

\begin{tabular}{lll}
\hline Week & Application Process & $\begin{array}{c}\text { Type of } \\
\text { Activity }\end{array}$ \\
\hline & $\begin{array}{l}\text { First of all, critical thinking dispositions of prospective Social Studies } \\
\text { teachers were determined through the California Critical Thinking }\end{array}$ & - \\
& Disposition Inventory (CCTDI) (pre-test). Later on, the prospective \\
& teachers were given a seminar on critical thinking and its importance \\
Week 1 & in Social Studies education. Finally, they were informed that "Today's \\
& $\begin{array}{l}\text { World Problems" course would be supported with writing-to-learn } \\
\text { activities for four weeks, and that they would be involved in relevant } \\
\\
\text { activities to improve their critical thinking skills. A holistic critical } \\
\text { thinking rubric was introduced for designing and evaluating writing- }\end{array}$
\end{tabular}
to-learn activities.

In the "Today's World Problems" course, based on the international migration happening in many regions of the world, especially from Syria, the past, present and future of the refugee issue in the world were comprehensively covered. Then, the participants were given the task of

Week 2 writing a letter by considering the fundamental components of holistic
critical thinking scoring rubric (recognizing the problem, recognizing

Letters different views, using evidence, avoiding prejudices, and making objective evaluations). The course was completed with the announcement that the assignment would be collected the following week.

In the "Today's World Problems" course, the issue of global terrorism was emphasized. By explaining the causes and consequences of the issue of terrorism, the impact of terrorist events on the world was thoroughly evaluated. Then, the participants were given the task of

Week 3 writing a column, taking into account the basic components of holistic critical thinking rubric (recognizing the problem, recognizing different views, using evidence, avoiding prejudices, and making objective evaluations). The assignments of letter writing from the previous week were collected for evaluation.

In the "Today's World Problems" course, nuclear energy was discussed in the classroom environment by taking the ideas of prospective teachers on nuclear energy under the heading of "Nuclear Energy, a Salvation or a Disaster?". The causes and consequences of nuclear energy were extensively studied. Later, the prospective teachers were given the task of writing a news article considering fundamental

Week 4 components of holistic critical thinking rubric (recognizing the problem, recognizing different views, using evidence, avoiding prejudices, and making objective evaluations). The assignments of column writing from the previous week were collected for evaluation. Finally, the letters were evaluated and given back to the participants so that they could be informed about how strong and weak they were in terms of critical thinking skills.

In the "Today's World Problems" Course, the subject of industrialization, which has an important place in social studies education, was discussed. The participants were told about the advantages and disadvantages of industrialization. Then, they were given a diary writing assignment to write by considering the

Week 5 fundamental components of holistic critical thinking rubric (recognizing the problem, recognizing different views, using evidence, avoiding prejudices, and making objective evaluations). The assignments of news article writing from the previous week were collected for evaluation. Finally, the columns were evaluated and 
distributed to the participants so that they could be informed about the progress they made in terms of critical thinking skills.

\begin{tabular}{ll}
\hline Week 6 & In the "Today's World Problems" course, the results of the diary writing \\
assignments were shared with the prospective teachers. Then, the - \\
critical thinking disposition post-tests of the participants were \\
determined through the California Critical Thinking Disposition \\
Inventory (CCTDI). Finally, the participants selected according to the \\
maximum variation sampling were interviewed about the effect of \\
writing-to-learn in the development of critical thinking skills. The \\
application process was completed.
\end{tabular}

\section{Data Analysis}

Normality analysis was performed to determine which parametric or nonparametric tests to use before proceeding with the data analysis obtained from the research. As a result of the normality analysis, the CCTDI data were found to show a normal distribution. The sub-scales of open-mindedness, self-confidence, truthseeking, and systematicity were observed to show normal distributions, while analyticity and inquisitiveness did not show normal distributions. Since the number of prospective teachers in the study group was 34, a Kolmogorov-Smirnov test was used for the normality analysis (Can, 2017; Karaatll, 2017). In addition to examining the histogram, normal Q-Q plot, detrended normal Q-Q plot graph, kurtosis and skewness values, an analysis was conducted to reveal whether or not the data showed normal distribution (Tabachnick \& Fidell, 2015; Pallant, 2005). Parametric and non-parametric tests were used as a result of the normality analysis. Inventory (CCTDI). Finally, the participants selected according to the maximum variation sampling

Data Analysis of the CCTDI. In the research process, the SPSS program was used to analyze the data obtained from CCTDI, which was applied to the prospective teachers as pre-test and post-test. The highest score that can be obtained from the critical thinking disposition inventory is 306 and the lowest is 51. Descriptive statistics were used to analyze the data obtained from CCTDI. Additionally, the paired samples t-test and Wilcoxon test were used to determine whether there was a statistically significant difference between the pre-test and post-test data of the study group. The effect size value was calculated in order to determine the extent of efficiency of the application. The effect size value was considered small when it was 0.2 , medium when it was 0.5, and large when it was 0.8 in size (Green \& Salkind, 2005; Can, 2017). In the research, these values were taken into account for the effect size.

Analysis of Writing-to-Learn Activities. Multiple writing-to-learn activities (letters, columns, new articles and diaries) were applied to improve the levels of critical thinking skills of the prospective Social Studies teachers. The writing-tolearn activities were evaluated by the researcher according to the holistic critical thinking rubric after the participants had done their weekly tasks. According to the critical thinking rubric, the highest score that can be obtained from an activity is 4 and the lowest is 1 . Based on this criterion, the activity of each participant was evaluated separately, as a result of which the participants were given feedback. In 
this way, the participants were given the opportunity to pursue their own development based on the process. The critical thinking scores obtained weekly, were written in a Microsoft Excel file. After calculating the weekly scores of each participant at the end of four weeks, the results were converted into tables and graphs. Thus, the levels of critical thinking skills of the prospective Social Studies teachers were evaluated each week and the development process was presented in a more understandable way.

Analysis of Data Obtained from Semi-Structured Interview Forms. Ten prospective teachers were interviewed in the study group in order to enable them to assess the application. The interviews were first transcribed verbatim by listening to the voice recorder and arranged in written texts. Content analysis was used in the analysis of the data obtained from the interviews. While analyzing the content, firstly, the data was carefully examined and codes were created. The codes were checked and similar codes were collected under appropriate categories. In order to ensure the reliability of the code and category creation process, two faculty members, who were experts in their fields, were given the data and asked to encode them independently from each other and collect them under appropriate categories. Then, reliability was calculated using Miles and Huberman's formula [(Reliability = number of agreements / (total number of agreements + number of disagreements)] for agreements and disagreements between researchers and experts. In general, it is desirable that this calculated reliability coefficient be $90 \%$ (Miles \& Huberman, 2016). In the reliability study applied in this study, a 95\% agreement (reliability) was achieved. After taking the expert opinion, necessary corrections were made and the analysis process was finalized. The findings were presented in tables. Codes such as PT/1, PT/2 ..... PT/10 were used while giving the statements from prospective teachers. The statements of prospective teachers were included in the form of direct quotations.

\section{Findings}

\section{The Effects of Writing-to-Learn Activities on Critical Thinking Skills}

In the first week of application, international migration and refugee issues were covered. Then, in the direction of certain principles, a "Letter" writing activity was implemented as one of the writing-to-learn activities. The findings on the prospective teachers' level of critical thinking skills from the given activity are shown in Table 4 and Figure 2.

Table 4

Levels of Critical Thinking Skills of Prospective Teachers Related to the First Week's Activity

\begin{tabular}{ll}
\hline Level of Critical Thinking Skills & $(\mathrm{f})$ \\
\hline Level 1 & 16 \\
Level 2 & 14 \\
Level 3 & 2 \\
Level 4 & 2 \\
\hline
\end{tabular}




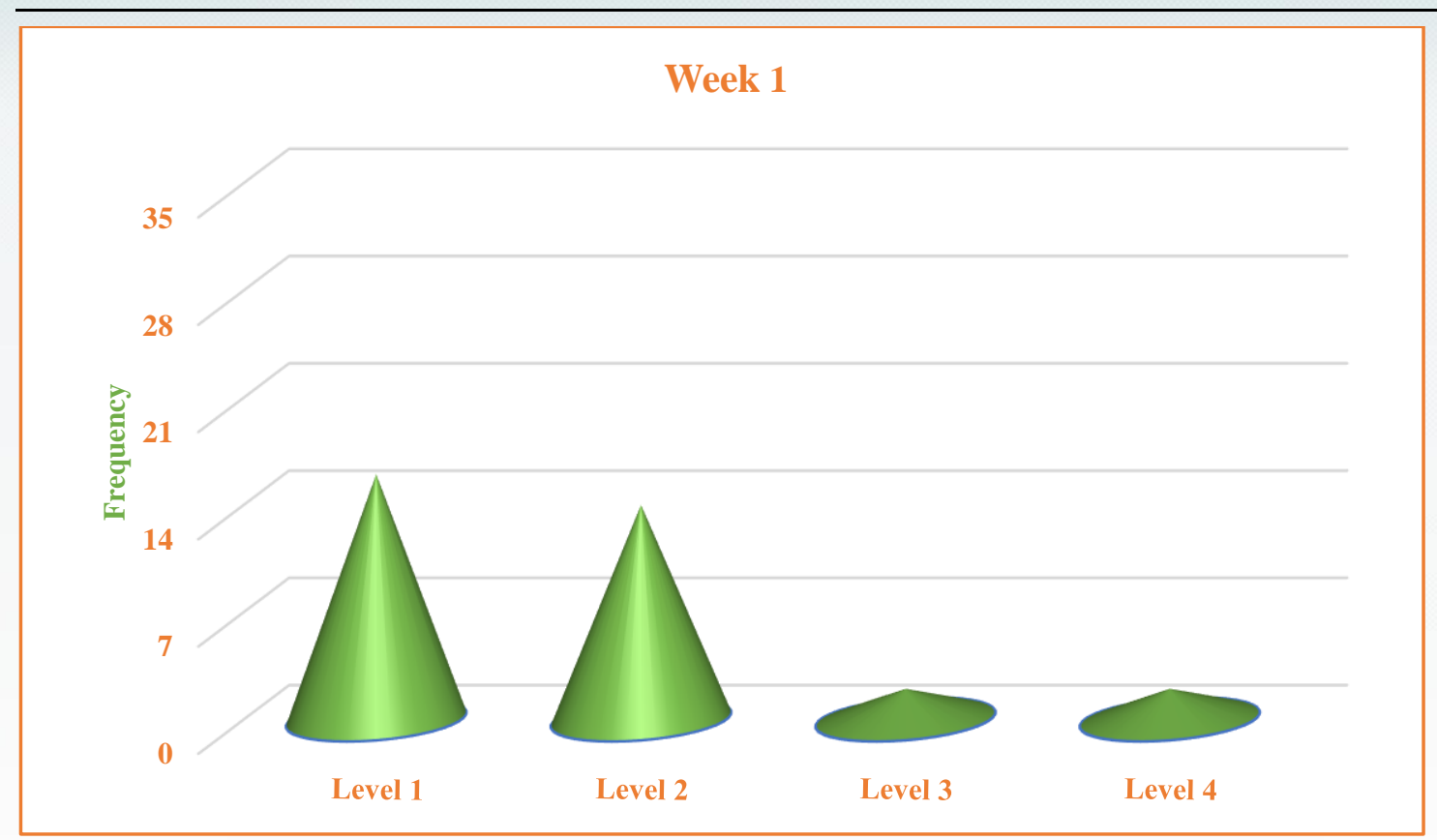

Figure 2. Levels of Critical Thinking Skills of Prospective Teachers related to the First Week's Activity.

On examining the "Letter" writing activity, we observed that 16 prospective teachers $(\mathrm{f}=16)$ were at Level 1 in terms of critical thinking skills in the first week, 14 prospective teachers $(\mathrm{f}=14)$ were at Level 2 , and two prospective teachers $(\mathrm{f}=2)$ were at Level 3, and two prospective teachers ( $\mathrm{f}=2$ ) were at Level 4. In other words, it can be argued that most of the prospective Social Studies teachers had a weak performance in terms of critical thinking skills. At this stage, the prospective teachers were biased in terms of critical thinking, distant to different views, showed a far from neutral evaluation, and had a poor ability at using evidence.

In the second week of the application, a "Column" writing activity was implemented as one of the writing-to-learn activities. The findings on the prospective teachers' level of critical thinking skills in regard to the activity given in the second week are presented in Table 5 and Figure 3.

Table 5

Levels of Critical Thinking Skills of Prospective Teachers Related to the Second Week's Activity

\begin{tabular}{ll}
\hline Level of Critical Thinking Skills & (f) \\
\hline Level 1 & 8 \\
Level 2 & 13 \\
Level 3 & 11 \\
Level 4 & 2 \\
\hline
\end{tabular}




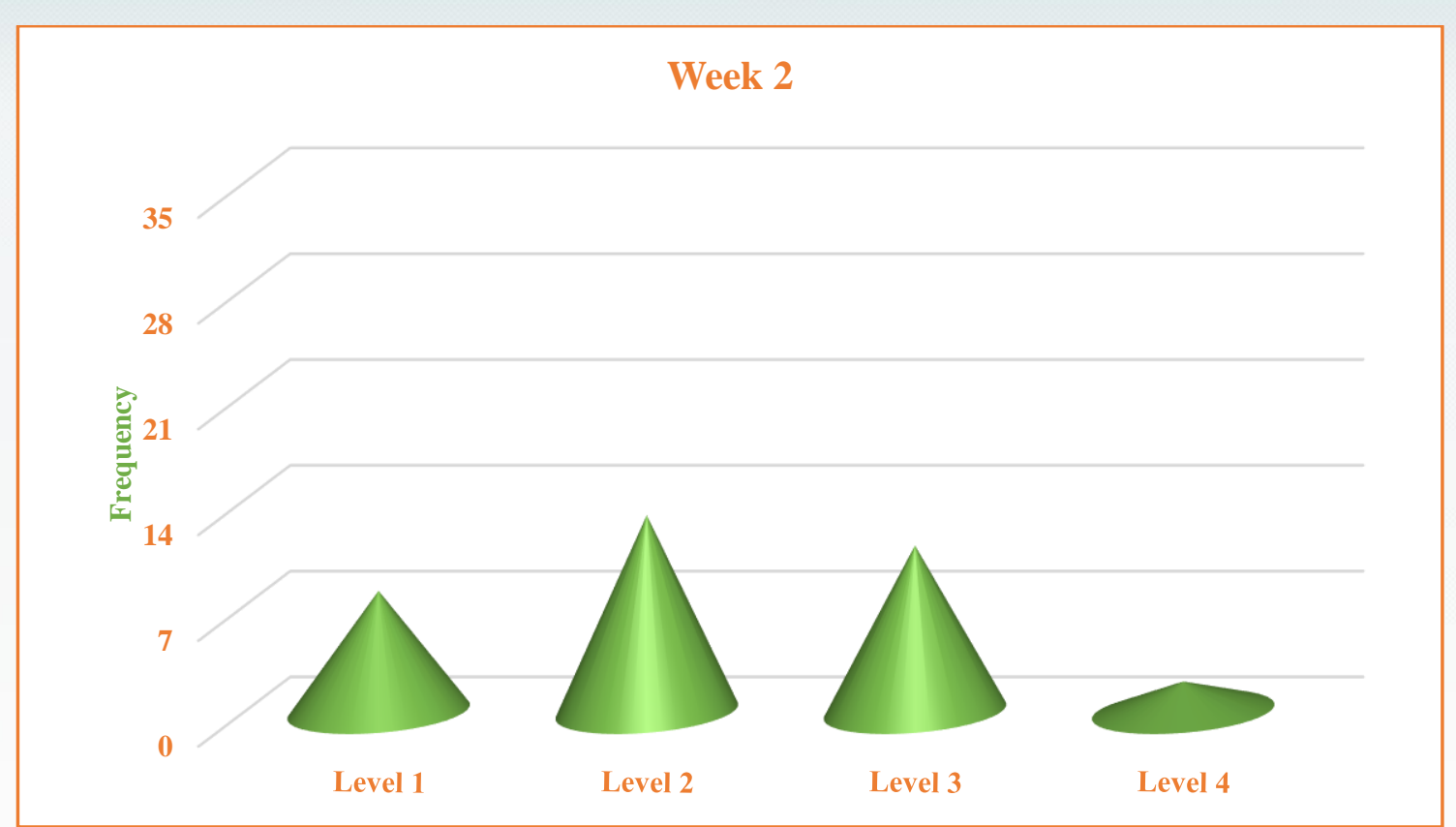

Figure 3. Levels of Critical Thinking Skills of Prospective Teachers Related to the Second Week's Activity.

On examining the "Column" writing activity, we observed that eight prospective teachers $(\mathrm{f}=8)$ were at Level 1 in terms of critical thinking skills in the second week; 13 prospective teachers $(\mathrm{f}=13)$ were at Level $2 ; 11$ prospective teachers $(\mathrm{f}=11)$ were at Level 3; and two prospective teachers $(\mathrm{f}=2)$ were at Level 4 . In other words, it can be argued that the prospective Social Studies teachers made progress in the second week compared to the first week in terms of the development of their critical thinking skills. At this stage, the prospective teachers started to move away from their prejudices in terms of critical thinking and they entered the process of taking different opinions into consideration and realized the importance of using evidence to support their claims.

In the third week of the application, a "News Article" writing activity was implemented as one of the writing-to-learn activities. The findings on the prospective teachers' level of critical thinking skills in regard to the activity given in the third week are presented in Table 6 and Figure 4.

Table 6

Levels of Critical Thinking Skills of Prospective Teachers Related to the Third Week's Activity

\begin{tabular}{ll}
\hline Level of Critical Thinking Skills & (f) \\
\hline Level 1 & 0 \\
Level 2 & 3 \\
Level 3 & 10 \\
Level 4 & 21 \\
\hline
\end{tabular}




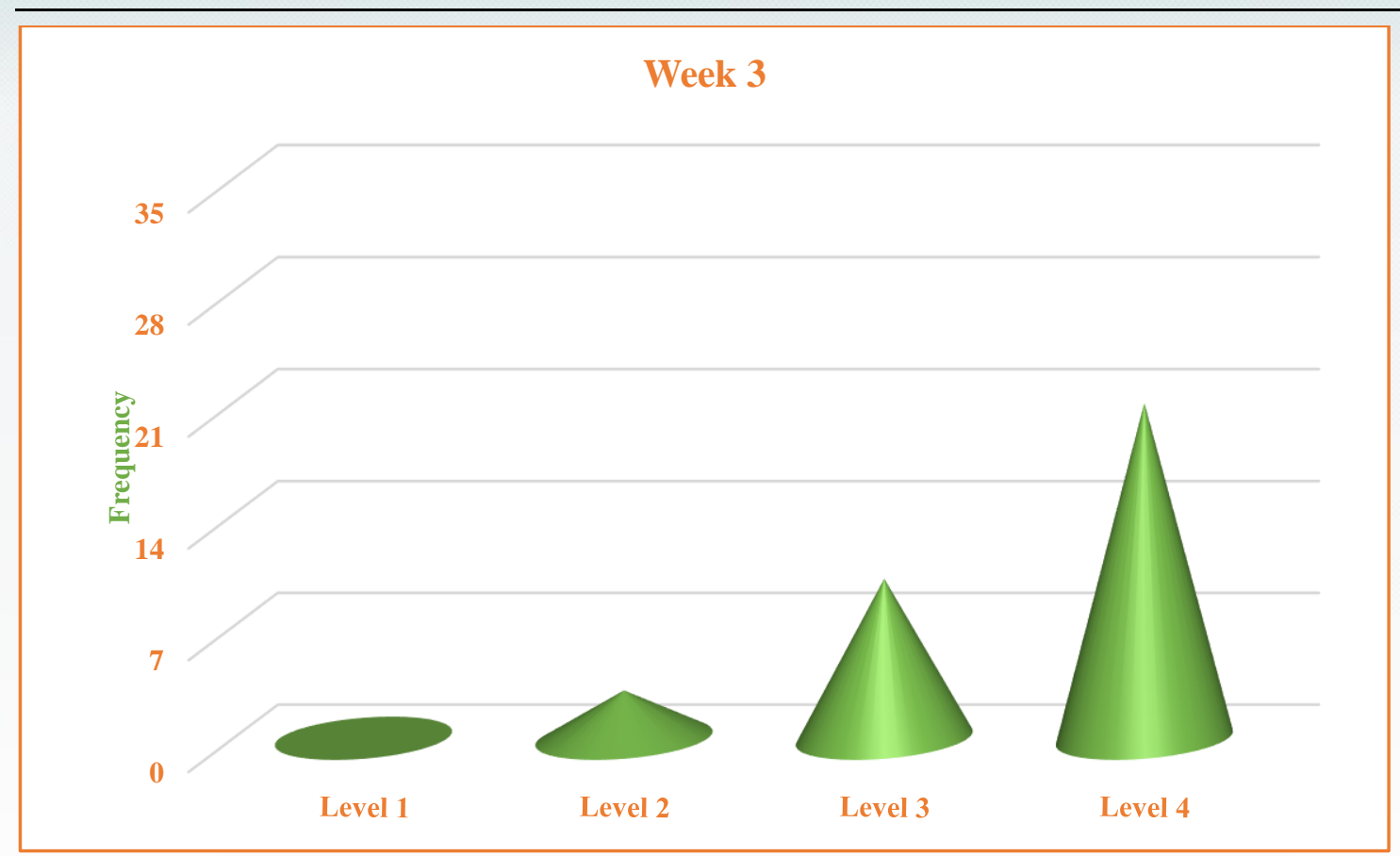

Figure 4. Levels of Critical Thinking Skills of Prospective Teachers Related to the Third Week's Activity.

On examining the "News Article" writing activity, we observed that no prospective teachers were at Level 1 in terms of critical thinking skills in the third week. However, three prospective teachers $(\mathrm{f}=3)$ were at Level 2; 10 prospective teachers $(\mathrm{f}=10)$ were at Level 3; and 21 prospective teachers $(\mathrm{f}=21)$ were at Level 4 . It is remarkable that majority of the prospective teachers reached Level 3 and Level 4 in the third week. At this stage, the prospective teachers were able to explain the problems with reason, and they become aware of their claims, were able to evaluate different opinions and support their claims with evidence, also, they were able to make an unbiased and objective assessment.

In the fourth week of the application, a "Diary" writing activity was implemented as one of the writing-to-learn activities. The findings on the prospective teachers' level of critical thinking skills in regard to the activity given in the fourth week are presented in Table 7 and Figure 5.

Table 7

Levels of Critical Thinking Skills of Prospective Teachers Related to the Fourth Week's Activity

\begin{tabular}{ll}
\hline Level of Critical Thinking Skills & $(\mathrm{f})$ \\
\hline Level 1 & 0 \\
Level 2 & 1 \\
Level 3 & 6 \\
Level 4 & 27 \\
\hline
\end{tabular}




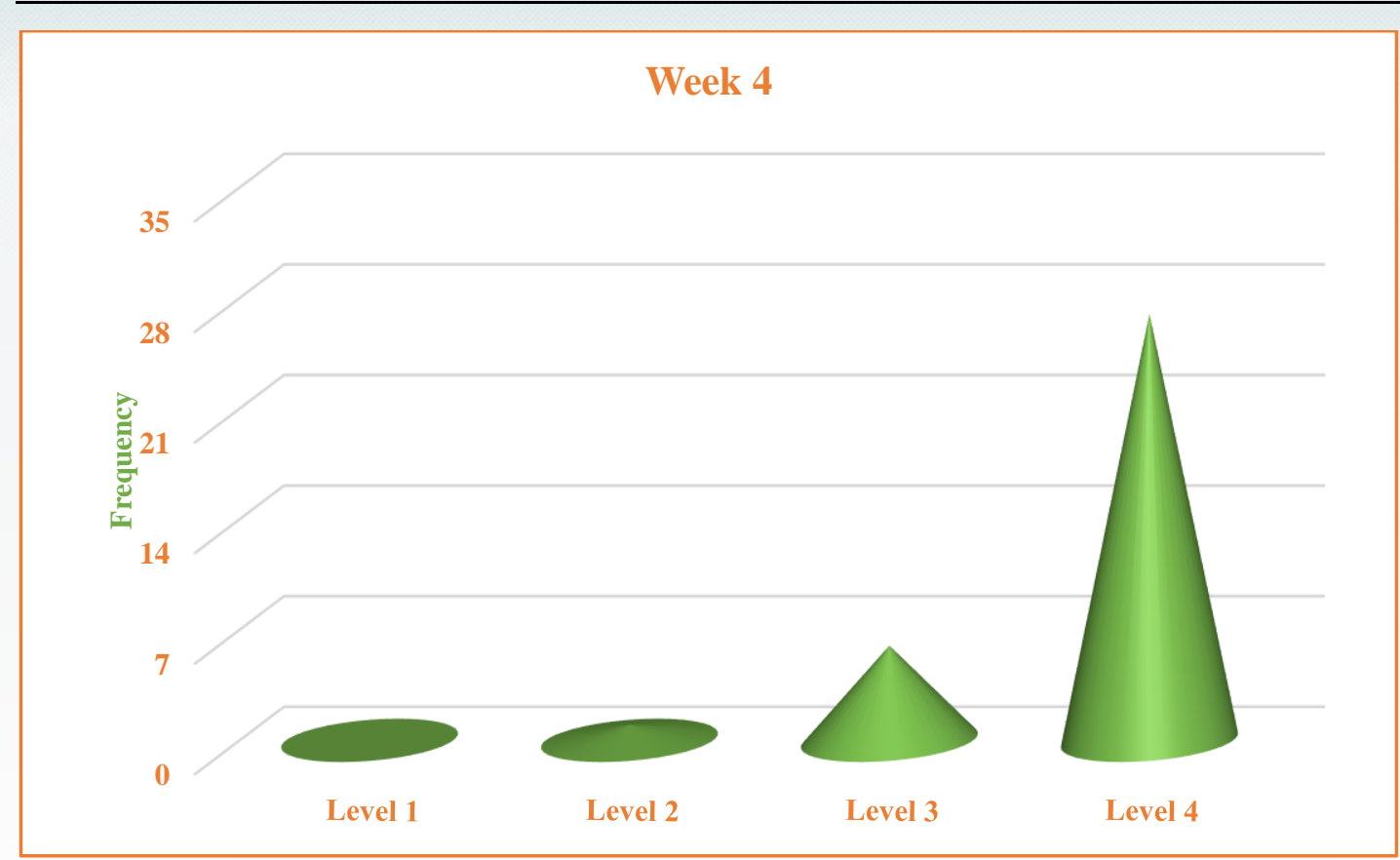

Figure 5. Levels of Critical Thinking Skills of Prospective Teachers Related to the Fourth Week's Activity.

On examining the "Diary" writing activity, we observed that no prospective teachers were at Level 1 in terms of critical thinking skills in the fourth week. Only one prospective teacher $(\mathrm{f}=1)$ was at Level 2 and six prospective teachers $(\mathrm{f}=6)$ were at Level 3. However, it is noteworthy that the vast majority of prospective teachers reached ( $\mathrm{f}=27$ ) Level 4 in the last week. It can be assumed that the prospective teachers achieved a higher level in terms of critical thinking skills by further improving the level reached in the third week when they got to the fourth week. At this stage, the participants were able to define the problem accurately, explain the claims and rationale of the subject, evaluate different ideas as a whole, reach definite and logical results and make accurate and unbiased evaluations.

The four-week development levels of prospective teachers are presented in Table 8 and Figure 6 as a whole in terms of critical thinking skills.

Table 8

The Four-Week Development Levels of Prospective Teachers in terms of Critical Thinking

\begin{tabular}{lllll}
\hline Level of Critical Thinking Skills & Week 1 & Week 2 & Week 3 & Week 4 \\
\hline Level 1 & 16 & 8 & 0 & 0 \\
Level 2 & 14 & 13 & 3 & 1 \\
Level 3 & 2 & 11 & 10 & 6 \\
Level 4 & 2 & 2 & 21 & 27 \\
\hline Total & 34 & 34 & 34 & 34 \\
\hline
\end{tabular}




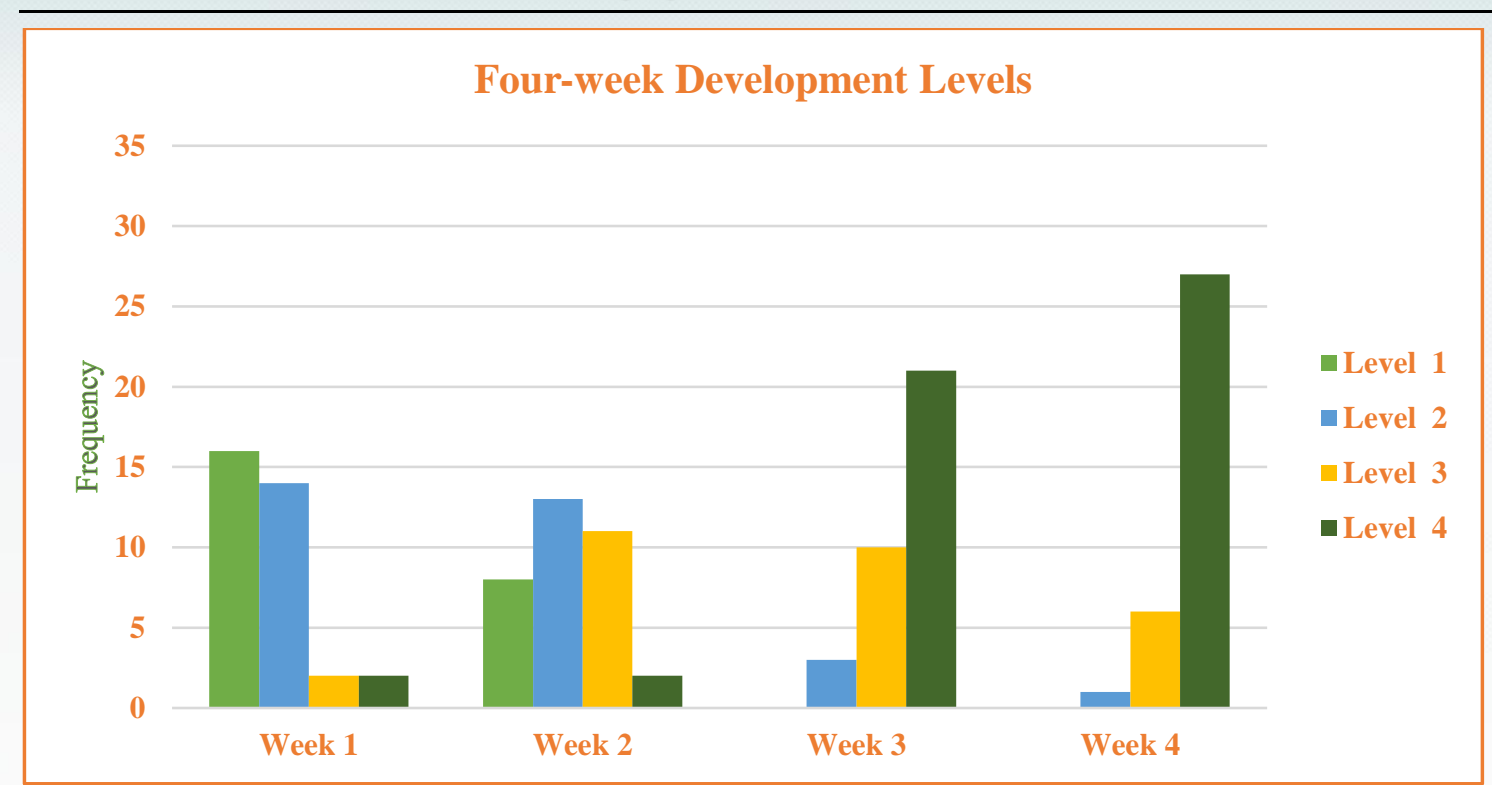

Figure 6. The Four-week Development Levels of Prospective Teachers in terms of Critical Thinking.

Table 8 and Figure 6 demonstrate that the levels of critical thinking skills of prospective Social Studies teachers showed a remarkable improvement within four weeks. The prospective teachers who were grouped at Level 1 in terms of their critical thinking skills in the first week of the application period gathered at Level 4 in the last week of the application period. In other words, while there were only two prospective teachers ( $f=2)$ at Level 4 of critical thinking skills in the first week of the application period, the number of prospective teachers at that level rose to $27 \mathrm{ff}$ $=27$ ) in the last week of the application. In the third and fourth weeks of the application, no prospective teacher remained at Level 1 in terms of critical thinking skills. Evidently, a significant quantitative change occurred between the first and the last week of application period in terms of the level of critical thinking skills.

In line with such findings, it can be assumed that writing-to-learn activities are effective in developing critical thinking skills of prospective Social Studies teachers.

\section{The Effect of Writing-to-Learn Activities on Critical Thinking Disposition}

The participants were given the CCTDI pre-tests and post-tests for the second question of the research in order to determine the effects of writing-to-learn activities on the critical thinking dispositions of prospective teachers. The suitability of CCTDI for the normal distribution of pre-testing data was examined using the Kolmogorov-Smirnov Normality test because the number of participants was over 30. The normality test results are given in Table 9 and Table 10.

Table 9

Kolmogorov-Smirnov Normality Test Results of the CCTDI Pre-test and Post-test Score Differences

\begin{tabular}{llll}
\hline CCTDI & Statistics & Sd & P \\
\hline $\begin{array}{l}\text { Pre-test-Post-test } \\
\text { (Score Differences) }\end{array}$ & .071 & 34 & $.200^{*}$ \\
\hline
\end{tabular}


On examining the results of the Kolmogorov-Smirnov normality analysis of the scores obtained from the CCTDI pre-test and post-test scores in Table 9, we observed that the scores showed a normal distribution ( $p=.200 ; p>.05)$. Table 10 demonstrates the results of the Kolmogorov-Smirnov normality test of the scores obtained from pre-test-post-test scores regarding the subscales of CCTDI.

Table 10

Kolmogorov-Smirnov Normality Test Results of the CCTDI Pre-test and Post-test Score Differences as to the Subscales

\begin{tabular}{llll}
\hline Subscale & Statistics & Sd & P \\
\hline Analyticity & .169 & 34 &. $\mathbf{0 1 5}$ \\
\hline Open-mindedness & .081 & 34 & $.200^{*}$ \\
\hline Inquisitiveness & .179 & 34 &. $\mathbf{0 0 7}$ \\
\hline Self-Confidence & .147 & 34 & .062 \\
\hline Truth-seeking & .091 & 34 & $.200^{*}$ \\
\hline Systematicity & .100 & 34 & $.200^{*}$ \\
\hline
\end{tabular}

Table 10 shows the analysis of the results of the Kolmogorov-Smirnov normality test scores obtained from the CCTDI pre-test and post-test score differences as to the sub-scales and demonstrates that the sub-scales of analyticity and inquisitiveness do not show normal distributions. However, the sub-scales of open mindedness, self-confidence, truth-seeking, and systematicity show normal distributions.

Since the CCTDI data were normally distributed, the paired samples t-test was used in the analysis of the data. Descriptive statistics and paired samples t-test results of the CCTDI data are presented in Table 11.

Table 11

Descriptive Statistics of the Scores of the CCTDI Pre-test and Post-test Data, and Paired Samples t-Test Results

\begin{tabular}{|c|c|c|c|c|c|c|}
\hline CCTDI & $\mathrm{N}$ & $\overline{\bar{X}}$ & Ss & $\mathrm{Sd}$ & $\mathrm{t}$ & $\mathrm{P}$ \\
\hline Pre-test & 34 & 191.85 & 19.56 & \multirow{2}{*}{33} & \multirow{2}{*}{-2.871} & \multirow{2}{*}{.007} \\
\hline Post-test & 34 & 206.00 & 16.61 & & & \\
\hline
\end{tabular}

Table 11 shows the descriptive statistics of the CCTDI pre-test and post-test data, indicating that the post-test average scores $(=206.00)$ of the prospective teachers are higher than those of the pre-test $(=191.85)$. Paired samples t-test was used in order to determine whether the difference between the pre-test and post-test mean scores was statistically significant. Table 11 also demonstrates a statistically significant difference between pre-test and post-test scores of prospective teachers based on the CCTDI data $(\mathrm{t}(33)=-2.871, \mathrm{p}<.05)$. The effect size value calculated as a result of the analysis was $d=0.50$, indicating a medium level effect. Descriptive statistics and paired samples t-test results as to the CCTDI subscales are presented in Table 12. 
Table 12

Descriptive Statistics of the Scores Obtained from the CCTDI Pre-test and Post-test Data as to the subscales and Paired Samples t-Test Results

\begin{tabular}{|c|c|c|c|c|c|c|c|}
\hline Subscales & & $\mathrm{N}$ & $\overline{\bar{X}}$ & Ss & $\mathrm{Sd}$ & $\mathrm{t}$ & $\mathrm{P}$ \\
\hline \multirow{2}{*}{$\begin{array}{l}\text { Open- } \\
\text { mindedness }\end{array}$} & Pre-test & 34 & 32.94 & 8.51 & \multirow{2}{*}{33} & \multirow{2}{*}{-8.314} & \multirow{2}{*}{.000} \\
\hline & Post-test & 34 & 48.11 & 6.20 & & & \\
\hline \multirow{2}{*}{ Self-Confidence } & Pre-test & 34 & 28.91 & 6.10 & \multirow{2}{*}{33} & \multirow{2}{*}{-.561} & \multirow{2}{*}{.579} \\
\hline & Post-test & 34 & 29.67 & 3.89 & & & \\
\hline \multirow{2}{*}{ Truth-seeking } & Pre-test & 34 & 23.00 & 6.35 & \multirow{2}{*}{33} & \multirow{2}{*}{-1.889} & \multirow{2}{*}{.068} \\
\hline & Post-test & 34 & 26.02 & 5.25 & & & \\
\hline \multirow{2}{*}{ Systematicity } & Pre-test & 34 & 19.97 & 3.91 & \multirow{2}{*}{33} & \multirow{2}{*}{-1.753} & \multirow{2}{*}{.089} \\
\hline & Post-test & 34 & 21.85 & 4.15 & & & \\
\hline
\end{tabular}

Table 12 shows the descriptive statistics of the CCTDI pre-test and post-test data as to the sub-scales, indicating that the increased post-test means scores of the prospective teachers. Paired samples t-test analysis was conducted to determine whether the difference between the pre-test and post-test mean scores of prospective teachers was statistically significant. Table 12 also demonstrates that, according to the CCTDI pre-test and post-test scores as to the sub-scales, there was a significant difference only in the sub-scale of open-mindedness ( $t(33)=-8.314, p$ $<.05$ ), while no significant difference was found among the sub-scales of selfconfidence, truth-seeking and systematicity. The effect size value calculated as a result of the analysis was $d=1.42$ for the sub-scale of open mindedness. This value was observed to have a huge impact on the sub-scale of open mindedness. As the sub-scales of analyticity and inquisitiveness did not show normal distributions, a Wilcoxon analysis was performed, and the results of the analysis are given in Table 13 and Table 14.

Table 13

Descriptive Statistics of the Scores Obtained from the CCTDI Pre-test and Post-test Data as to the Subscales

\begin{tabular}{lllll}
\hline Subscales & & $\mathrm{N}$ & $\bar{X}$ & Ss \\
\hline \multirow{2}{*}{ Analyticity } & Pre-test & 34 & 46.76 & 7.05 \\
& Post-test & 34 & 45.76 & 6.65 \\
\hline \multirow{2}{*}{ Inquisitiveness } & Pre-test & 34 & 40.11 & 6.44 \\
& Post-test & 34 & 34.55 & 5.18 \\
\hline
\end{tabular}

Table 13 shows the descriptive statistics of the CCTDI pre-test and post-test data, indicating that there is a decrease in the post-test mean scores of the prospective teachers. A Wilcoxon analysis was conducted to determine whether the difference between the pre-test and post-test mean scores of prospective teachers was statistically significant. Analysis results are presented in Table 14. 
Kayaalp, F., Meral, E., Șimșek, U., Sahin, I. F. (2020). A Search for a Method to Improve Critical....

Table 14

Wilcoxon Test Results of CCTDI Pre-test and Post-test Data Scores as to the Subscales

\begin{tabular}{llllll}
\hline $\begin{array}{l}\text { Subscale } \\
\text { Analyticity }\end{array}$ & $\mathrm{N}$ & Mean Rank & Total & $\mathrm{Z}$ & $\mathrm{P}$ \\
\hline Negative Ranks & 16 & 15.16 & 249.00 & & \\
Positive Ranks & 14 & 15.43 & 216.00 & -.340 & .734 \\
Ties & 4 & & & & \\
\hline Subscale & $\mathrm{N}$ & Mean Rank & Total & $\mathrm{Z}$ & $\mathrm{P}$ \\
Inquisitiveness & & & & & \\
\hline Negative Ranks & 27 & 17.91 & 483.50 & & -3.183 \\
Positive Ranks & 7 & 15.93 & 111.50 & & \\
Ties & 0 & & & & \\
\hline
\end{tabular}

Table 14 shows the data obtained from the CCTDI subscales of analyticity and inquisitiveness, indicating that there was no statistically significant difference in the sub-scale of analyticity between the pre-test and post-test scores of the prospective teachers $(\mathrm{z}=-.340, \mathrm{p}>.05)$, while a significant difference was found as to the subscale of inquisitiveness $(\mathrm{z}=-3.183, \mathrm{p}<.05$. $)$. The effect size value calculated as a result of the analysis was $r=0.38$ for the sub-scale of inquisitiveness. This value was found to have a minor effect on the sub-scale of inquisitiveness.

\section{The Opinions of Prospective Teachers about the Use of Writing-to-Learn Activities}

The prospective teachers were first asked: "Do you think that writing-to-learn activities improve your critical thinking skills? Why? / Why not?" The opinions of prospective teachers and some direct quotations about their views as to this question are given in Table 15 below.

Table 15

Prospective Teachers' Opinions on the Effect of Writing-to-Learn Activities on Critical Thinking Skills

\begin{tabular}{|c|c|c|}
\hline Category & $\begin{array}{l}\text { Prospectiv } \\
\text { e Teachers }\end{array}$ & Some Selected Views of Prospective Teachers \\
\hline Enabling research & $\begin{array}{l}\mathrm{PT}_{10}, \mathrm{PT}_{9} \\
\mathrm{PT}_{6}, \mathrm{PT}_{1}\end{array}$ & $\begin{array}{l}\text { "Thanks to writing, people can look at the events or } \\
\text { topics from a wider perspective by reading and } \\
\text { researching different sources and evaluating the } \\
\text { opinions of different people on the same subject. This } \\
\text { improves people's critical thinking skills. PT/9." }\end{array}$ \\
\hline Directing to think & $\mathrm{PT}_{8}, \mathrm{PT}_{2}$ & $\begin{array}{l}\text { "The human brain is something that develops as people } \\
\text { write, think, and convey their thoughts. Writing makes } \\
\text { people think. The more we think about a subject, the } \\
\text { more progress we get. PT/2." }\end{array}$ \\
\hline $\begin{array}{l}\text { Encouraging to make } \\
\text { comprehensive } \\
\text { explanations }\end{array}$ & $\mathrm{PT}_{4}, \mathrm{PT}_{3}$ & $\begin{array}{l}\text { "I think that while people write, they are able to express } \\
\text { and remember more freely the ideas that they cannot } \\
\text { think of in verbal communication. This allows them to } \\
\text { explain the subject more broadly. PT / 4." }\end{array}$ \\
\hline $\begin{array}{l}\text { Giving the opportunity } \\
\text { to recognize different } \\
\text { ideas }\end{array}$ & $\mathrm{PT}_{5}$ & $\begin{array}{l}\text { "Researching the subject and evaluating different } \\
\text { opinions definitely make a positive contribution to the } \\
\text { critical thinking skills of people. PT / 5." }\end{array}$ \\
\hline
\end{tabular}




\begin{tabular}{ll}
\hline $\begin{array}{l}\text { Providing resource- } \\
\text { based explanations }\end{array}$ & "Thanks to writing, you do research, you always get the \\
& $\begin{array}{l}\text { opportunity to get out of what you know, you get } \\
\text { information from different sources, and naturally, this } \\
\text { improves your critical thinking skills. PT/7." }\end{array}$ \\
\hline
\end{tabular}

Table 15 shows that the prospective teachers expressed their opinions about the potential of writing-to-learn activities related to critical thinking skills by emphasizing such factors as enabling research, directing them to thinking, encouraging them to make comprehensive explanations, giving them the opportunity to recognize different ideas, and providing source-based explanations.

Table 16 presents the responses given to the research question: "Which one of the writing-to-learn activities do you think is more effective to develop your critical thinking skills? Can you explain?", including the opinions of the prospective teachers and some direct quotations about their views as to the given question.

Table 16

Prospective Teachers' Opinions on More Effective Writing-to-Learn Activities on Critical Thinking Skills

\begin{tabular}{|c|c|c|}
\hline Category & $\begin{array}{l}\text { Prospective } \\
\text { Teachers }\end{array}$ & Some Selected Views of the Prospective Teachers \\
\hline News Article & $\mathrm{PT}_{1}, \mathrm{PT}_{6}, \mathrm{PT}_{7}$ & $\begin{array}{l}\text { "Writing news articles is an activity that really pushes people } \\
\text { to do research. So, it can absolutely be applied to improve the } \\
\text { critical thinking skills. PT/ 1." }\end{array}$ \\
\hline Column & $\mathrm{PT}_{3}, \mathrm{PT}_{10}$ & $\begin{array}{l}\text { "I think it is the column writing. It can be written by } \\
\text { highlighting the research without any aesthetic concern (i.e. } \\
\text { spelling and punctuation). PT/3." }\end{array}$ \\
\hline $\begin{array}{l}\text { Letter, News } \\
\text { Article, Diary, } \\
\text { Column }\end{array}$ & $\mathrm{PT}_{8}, \mathrm{PT}_{9}$ & $\begin{array}{l}\text { "I think all of them have distinct effects on the development of } \\
\text { critical thinking skills. While some activities develop thinking, } \\
\text { some highlight research, while others prioritize considering } \\
\text { research, thinking and the opinions of different people. All of } \\
\text { these have an impact on critical thinking processes. PT / 8." }\end{array}$ \\
\hline Letter, Diary & $\mathrm{PT}_{2}$ & $\begin{array}{l}\text { "In the letter and diary writing activity, one's ideas are revealed } \\
\text { in every aspect. So, I care about these activities in the } \\
\text { development of critical thinking. PT/2". }\end{array}$ \\
\hline Letter & $\mathrm{PT}_{4}$ & $\begin{array}{l}\text { "I think the most effective would be the letter writing. I had the } \\
\text { opportunity to explain my own thoughts completely accurately } \\
\text { and effectively. PT/4". }\end{array}$ \\
\hline Diary & $\mathrm{PT}_{5}$ & "Diary..., because ideas come up in all aspects. PT/5." \\
\hline
\end{tabular}

Table 16 shows that two prospective teachers $(\mathrm{f}=2)$ found news articles to be effective as a writing-to-learn activity from which to develop their critical thinking skills. Two prospective teachers $(\mathrm{f}=2)$ found writing columns to be effective for developing critical thinking skills and one prospective teacher $(\mathrm{f}=1)$ found writing letters to be effective, and one prospective teacher $(\mathrm{f}=1)$ found keeping diaries to be more effective in developing critical thinking skills. In addition, two prospective teachers $(\mathrm{f}=2)$ stated that all writing activities were effective, and one prospective teacher $(\mathrm{f}=1)$ expressed that using letters and diaries was more effective in developing their critical thinking skills.

Table 17 presents the responses given to the research question: "What are the positive or negative aspects of using writing-to-learn activities? Can you explain?", 
including the prospective teachers' opinions and some direct quotations about their views as to the given question.

Table 17

Prospective Teachers' Opinions as to the Positive and Negative Aspects of Using Writing-toLearn Activities

\begin{tabular}{|c|c|c|}
\hline Category & $\begin{array}{l}\text { Prospective } \\
\text { Teachers }\end{array}$ & Some Selected Views of the Prospective Teachers \\
\hline Inquisitiveness & $\mathrm{PT}_{8}, \mathrm{PT}_{9}$ & $\begin{array}{l}\text { "I see that there are so many advantages to writing. If I am to } \\
\text { count them, I would say that the development of research skills } \\
\text { arouses curiosity and provides different ideas. PT/9." }\end{array}$ \\
\hline $\begin{array}{l}\text { Versatile } \\
\text { Thinking Skills }\end{array}$ & $\mathrm{PT}_{4}, \mathrm{PT}_{5}$ & $\begin{array}{l}\text { "The positive aspect of writing activities is that they enable } \\
\text { doing research and lead to multi-faceted thinking. PT/4." }\end{array}$ \\
\hline Self-expression & $\mathrm{PT}_{10} \mathrm{PT}_{7}$ & $\begin{array}{l}\text { "While writing, the person is alone with oneself. It can reveal } \\
\text { original thoughts. PT/7." }\end{array}$ \\
\hline $\begin{array}{l}\text { Gaining Research } \\
\text { Skills }\end{array}$ & $\mathrm{PT}_{2}$ & $\begin{array}{l}\text { "In every sense, the way to learn and acquire knowledge is } \\
\text { through research. Research is also important when writing. } \\
\text { However, we can write as much as we research. PT/2." }\end{array}$ \\
\hline $\begin{array}{l}\text { Getting to Know } \\
\text { Different Ideas }\end{array}$ & $\mathrm{PT}_{3}$ & $\begin{array}{l}\text { "Although writing is time consuming for the teacher, it } \\
\text { provides a student with the opportunity to learn about the } \\
\text { opinions of different people on the same subject. PT/3." }\end{array}$ \\
\hline Using Evidence & $\mathrm{PT}_{6}$ & $\begin{array}{l}\text { "It is necessary to do research and get some information before } \\
\text { writing. The information obtained is evidence for us in } \\
\text { explaining our thoughts. PT/6." }\end{array}$ \\
\hline $\begin{array}{l}\text { Getting } \\
\text { Information }\end{array}$ & $\mathrm{PT}_{1}$ & $\begin{array}{l}\text { "The most important advantage of writing is that it expands } \\
\text { our knowledge. PT/1." }\end{array}$ \\
\hline Time Consuming & $\begin{array}{l}\mathrm{PT}_{1}, \mathrm{PT}_{2} \\
\mathrm{PT}_{4}, \mathrm{PT}_{5}\end{array}$ & $\begin{array}{l}\text { "Expressing yourself and recapping the topic is time } \\
\text { consuming. PT/5." }\end{array}$ \\
\hline
\end{tabular}

Table 17 shows that the prospective teachers expressed their opinions about the positive aspects of writing-to-learn activities such as inquisitiveness, versatile thinking, self-expression, research, recognizing different ideas, using evidence and obtaining information. However, it was found that only four prospective teachers $(\mathrm{f}=4)$ expressed that writing-to-learn activities were time-consuming as a negative aspect.

Finally, Table 18 presents the responses given to the research question: "Would you prefer to use writing-to- learn activities when you become a teacher? Why/Why not?", including the prospective teachers' opinions and some direct quotations about their views as to the given question. 
Table 18

Opinions of Prospective Teachers about the Willingness to Use Writing-to-Learn Activities

\begin{tabular}{|c|c|c|}
\hline Category & $\begin{array}{l}\text { Prospective } \\
\text { Teachers }\end{array}$ & Some Selected Views of the Prospective Teachers \\
\hline $\begin{array}{l}\text { Directing to } \\
\text { think }\end{array}$ & $\begin{array}{l}\mathrm{PT}_{5}, \mathrm{PT}_{6}, \mathrm{PT}_{7} \\
\mathrm{PT}_{8}, \mathrm{PT}_{9}, \mathrm{PT}_{10}\end{array}$ & $\begin{array}{l}\text { "No matter how challenging it is, what is important to me is to } \\
\text { add something to the students as a teacher. These activities will } \\
\text { make important contributions to my students' development of } \\
\text { critical thinking skills. PT /5." }\end{array}$ \\
\hline $\begin{array}{l}\text { Enabling self- } \\
\text { expression }\end{array}$ & $\begin{array}{l}\mathrm{PT}_{1}, \mathrm{PT}_{2} \\
\mathrm{PT}_{3}, \mathrm{PT}_{4}\end{array}$ & $\begin{array}{l}\text { "Writing is the most important and nicest way to express your } \\
\text { thoughts. That's why writing is a great opportunity to explain } \\
\text { our opinions on what we have learned. So, I will use writing } \\
\text { activities in my teaching life. PT/1." }\end{array}$ \\
\hline
\end{tabular}

Table 18 shows that the prospective teachers stated their willingness to use writing-to-learn activities to encourage students to think and to express themselves.

\section{Discussion}

This study evaluated the impact of writing-to-learn activities on developing levels of critical thinking skills amongst prospective Social Studies teachers; the study also discussed the change in critical thinking dispositions of the prospective Social Studies teachers at the end of this process. The reasons for the change were evaluated comprehensively from the opinions of the prospective teachers about writing-to-learn activities. The research findings show that writing-to-learn activities provided an improvement in the levels of critical thinking skill demonstrated by the prospective Social Studies teachers; also, a significant difference emerged in their critical thinking dispositions. The result is parallel to many other studies in the literature (Burhanuddin \& Ibrahim, 2019; Hobson \& Schafermeyer, 1994; Giroux, 1978; Gupta et al., 2015; Hooey \& Bailey, 2005; Nejmaoui, 2019; Quitadamo \& Kurtz, 2007, Sinaga \& Feranie, 2017; Stephenson \& Sadler-McKnight, 2016; Walp, 2013). The first reason for this change that occurs in both the critical thinking dispositions and the critical thinking skills is that the writing-to-learn activities arouse curiosity about the subject and lead the prospective teachers to think and do more in-depth research. Considering this situation, PT/2 states that "In every sense, the way to learn and acquire knowledge is through research. Research is also important when writing. However, we can write as much as we research." In other words, this participant emphasizes the importance of research in the process of critical thinking. PT/9 suggests that writing-to-learn activities provide the opportunity to get to know different views about the same subject as well as comprehensive information: "Thanks to writing, people can look at events or topics from a wider perspective through reading and researching different sources and evaluating the opinions of different people on the same subject. This improves people's critical thinking skills". Again, the third reason for this change is that writing-to-learn activities give participants the chance to support their knowledge with different sources. The reason for this change is reflected in the thoughts of PT/7 who states that: " Thanks to writing, you do research, you always get the opportunity to get out of what you know, you get information from different sources, and naturally, this improves your critical 
thinking skills." Pertaining to the change on critical thinking, PT/1 states that "Writing is the most important and nicest way to express your thoughts. That's why writing is a great opportunity to explain our opinions on what we have learned.", indicating the fourth reason for the change created by writing-to-learn activities by generating the ability in students to think multi-dimensionally and to interpret that topic by reviewing the information they have obtained over and over again. The last reason for the change caused by writing-to-learn activities on critical thinking skills is that participants who obtain information through writing-to-learn activities can make an objective assessment by giving evidence-based explanations on their opinions and by considering different opinions as well as the information they obtain. On the evaluation process, PT/7 stated that, "While writing, the person is alone with oneself. It can reveal original thoughts", assigning a different meaning to the process. There appears a noticeable similarity between the reasons behind this change in the prospective teachers and the skills of "interpretation, analysis, evaluation, inference, explanation" put forward by Facione (1990) for critical thinking. Considering this situation observed in the findings of the study in relation to different studies in the literature, many studies were observed to have similar results with this study. There are also a few studies (Daşdemir, 2017; Uzoğlu, 2014), which obtained results different from those of this study.

Pointing out that writing is a bridge between what is already known and what is want to be known, Hooey and Bailey (2005) state that writing encourages students to become active learners and critical thinkers. Therefore, writing contributes significantly to the development of critical thinking skills which indicates a similarity with the results of the current study in which the improvement of prospective teachers is highlighted pertaining to doing research. Again, Walp (2013), who integrated writing into learning environments, revealed a parallel result with this study by stating that writing enables the comparison of similarities and differences in learning processes, and supports establishing cause and effect relationship, and accelerates the development of critical thinking in students. Vanorden (1987), who brought a different perspective to the contribution of writing-to-learn activities to critical thinking, stating that writing-to-learn promotes thinking skills and this emerging mental process is shaped in four steps such as decision making, knowledge acquisition, knowledge use and evaluation of information. Vanorden (1987), who stressed the contribution of writing-to-learn to the development of critical thinking, came up with a result of supporting the features such as versatile thinking skills, and promoting research and evaluation, which are from among the effects of writing-to-learn on critical thinking frequently expressed in this study.

Trying to develop critical thinking through Science Writing Heuristic (SWH), which is one of the types of writing-to-learn model, Stephenson and SadlerMcKnight (2016), stated that writing activities put students in a mental process such as questioning, combining and evaluating what they learn. Stephenson and SadlerMcKnight (2016) assert that writing activities used in classrooms and learning environments are much more effective than traditional approaches in the development of critical thinking skills. Thus, their results support the results from the current study in many respects such as inquisitiveness, pondering, and making 
judgments in the critical thinking process. Like Stephenson and Sadler-McKnight (2016), Gupta et al., (2014), who also incorporated the SWH into learning environments, states that writing-to-learn activities include features such as recognizing different ideas, using evidence when explaining ideas or claims, as well as interpreting and evaluating, which are all crucial for critical thinking. Results came to a parallel conclusion with both this current study and that of Stephenson and Sadler-McKnight (2016). Like many researchers, both Quitadamo and Kurtz (2007) and Erkan (2008), who tried to reveal the effects of writing on the development of critical thinking, explained that writing activities used in classrooms and learning environments develop many aspects of critical thinking, especially analysis and evaluation skills. These results tend to support the reasons for the change in critical thinking expressed by many participants from the current research. In addition, Burhanuddin and Ibrahim (2019), pointed out that writing is one of the most effective ways to develop critical thinking, and that writing is the sum of the ideas that come out as a result of a mental process. The perspective expressed by Burhanuddin and Ibrahim (2019) for writing has a close similarity with that of the PT/2 stating: The human brain is something that develops as people write, think, and convey their thoughts. Writing makes people think. The more we think about a subject, the more progress we get". According to Sinaga and Feranie (2017), who discussed critical thinking through writing-to-learn activities, students get the opportunity to read and review what they have written in analysing their evidence while making their claims in the process of writing. Their assertion that this situation naturally makes important contributions to the development of students' critical thinking processes has a common feature with this research: emphasizing the use of argument, evidence, and evaluation in the critical thinking process, which are presented as the causes of change in the current study. Stating that writing activities increase students' critical thinking skills by affecting their participation and decision-making processes, Knipper and Duggan (2006) drew attention to the similar reasons for the change in critical thinking skills as stated in this research to explain the multi-dimensional relationship between writing and critical thinking.

There are a number of studies with similar features with this study, as well as those that reach different findings and conclusions, and even those concluding that learning activities are not effective on critical thinking. Involving writing-to-learn activities into learning environments for the sake of improving students' critical thinking skills, Daşdemir (2017) obtained a different result from this research. Similarly, utilizing writing-to-learn activities in the development of critical thinking as Daşdemir (2017) did, Uzoğlu (2014) stated that writing-to-learn activities were ineffective in developing critical thinking skills while developing students in different aspects (academic achievement, attitude towards the course). The fact that there are different results between this study and others can be explained by multiple reasons. The first of these reasons can be attributed to the type of writingto-learn activity used in the studies to develop critical thinking. The current study employed a variety of writing-to-learn activities (news articles, columns, diaries, and letters), which enable prospective teachers to develop their critical thinking skills. However, Uzoğlu (2014) included a letter and a diary in the study, while Daşdemir (2017) included only a letter as a writing-to-learn activity. As the second 
reason, it can be assumed that the variations were caused by the strategies followed during the application and data collection processes. During the application phase of this study, a process and result-oriented path was followed while collecting data. Such particular emphasis was placed on process-based assessment that every activity was evaluated weekly according to the holistic critical thinking scoring rubric, and prospective teachers were given feedback about their development in critical thinking skills. Such feedback made a significant contribution to prospective teachers in that they were able to realize their strengths and weaknesses in terms of critical thinking skills. The development of prospective teachers in the process was also reflected in the result. Considering the application and evaluation processes of the studies with results different from this study, both Uzoğlu (2014) and Daşdemir (2017) preferred to evaluate critical thinking skills based on results rather than processes. The reason why a significant change did not occur in terms of critical thinking in their works is that both Daşdemir (2017) and Uzoğlu (2014) explained that the development of critical thinking skills in individuals require a long process.

\section{Conclusions and Suggestions}

The first result obtained in this research is that the prospective Social Studies teachers experienced a positive change in regard to critical thinking skills, which is an attempt to think in the face of a problem or event, through using writing-to-learn activities. This positive change experienced by the prospective Social Studies teachers during the process of the research increased their "willingness to think critically". Such a finding revealed a significant change in the critical thinking dispositions of the prospective Social Studies teachers which is the second result of this research. The third conclusion reached in the research is that the prospective Social Studies teachers proposed multi-dimensional thoughts about writing-tolearn activities. The prospective teachers in this study highlighted the change observed in the dimensions of dispositions and skills by indicating that a writing-tolearn model can be an effective teaching model in the development of critical thinking, and that these activities contribute to the theoretical structure of critical thinking. The prospective Social Studies teachers even declared that they would use writing-to-learn activities in their teaching profession.

The result of this research is presented in Figure 7 as a whole, considering both "how" the critical thinking has developed over the writing-to-learn teaching model and "why" writing-to-learn activities are effective on critical thinking. Article text. Editing field. [C\&S] 


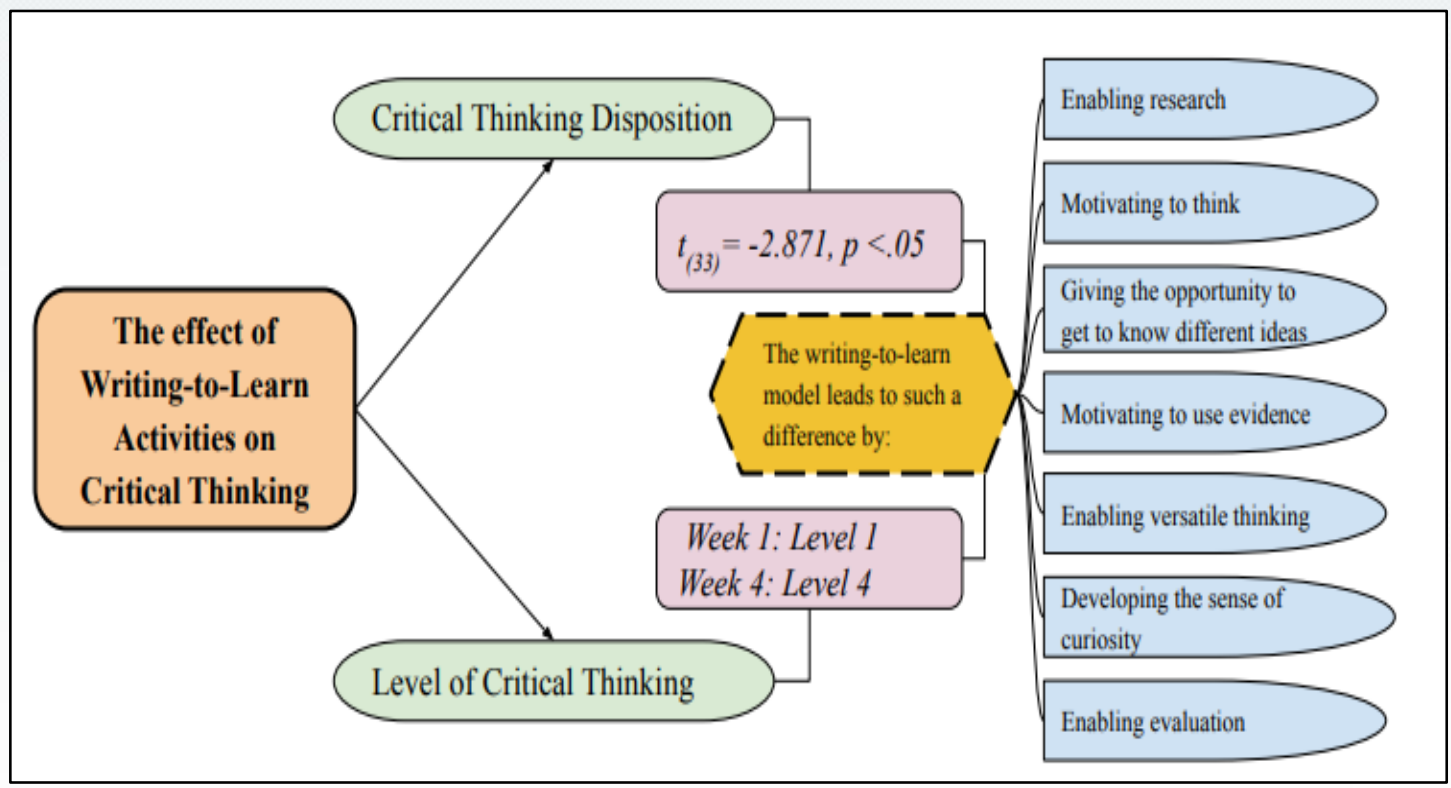

Figure 7. Study Results

Figure 7 also shows the multiple effects of writing-to-learn activities on the development of critical thinking skills. Despite revealing such multiple effects reflected in the result, this research has some limitations.

The first limitation of this study is that the research was carried out with the participation of 34 prospective Social Studies teachers. The second limitation is that four different writing-to-learn activities were used on four different topics in Today's World Problems course.

Considering the findings and results of the research, the following suggestions for researchers and practitioners have been put forward

- This study revealed that the critical thinking skills of prospective teachers improved through the use of writing-to-learn activities in their study of Today's World Problems course. Writing-to-learn activities can be used in different courses and subjects.

- This study was conducted on the development of critical thinking skills. Further research can be conducted to develop different higher-order thinking skills through writing-to-learn activities.

- The prospective Social Studies teachers are the working group of this research. Similar studies can be conducted with different study groups.

- Four different writing-to-learn activities were used in this research. Similar studies can be conducted with different writing-to-learn activities. 


\section{References}

Açar, S. (2010). The title of this study is to examine the effects of expedition in Social studies lesson in primary school on the students' critical thinking skills and environmental sensitivity (Unpublished master's thesis). Çanakkale Onsekiz Mart University, Çanakkale, Turkey.

Al-Khayyatt, A.A. (1980). An experimental study comparing the effects of the inquiry method and the traditional method for teaching social studies in two Kuwaiti secondary schools for boys (Doctoral Dissertation). Retrieved from ProQuest Dissertations \& Theses Global.

Allen, A. (2018). Teach like Socrates: Encouraging critical thinking in elementary social studies. Social Studies and the Young Learner, 31(1), 4-10. Retrieved from https:// eric.ed.gov/?id = EJ 1224890

Anisaroh, A., Roesminingsih, M. V., \& Suyanto, V. (2018). Implementation of problem-based learning to improve the critical and creative thinking skills. 2nd International Conference on Education Innovation (ICEI 2018), doi: 10.2991/icei-18.2018.7

Ashworth, T. E. (1992). Using writing-to-learn strategies in community college associated degree nursing programs (Doctoral dissertation). Retrieved from https:// vtechw orks.lib.vt.edu

Baştürk, G. (2019). Impact of authentic learning practices on students 'critical thinking skills and attitudes towards social studies (Unpublished master's thesis). Sakarya University, Sakarya, Turkey.

Boucher, M. J. (2010). Maps: Developing critical thinking skills for deaf students in a social studies curriculum. Retrieved from ProQuest Dissertations \& Theses Global.

Bozkurt, R. (2017). The effect of argumentation-based inquiry approach supported by upper cognitive activities on science achievement of preservice teachers (Unpublished master's thesis). Kastamonu University, Kastamonu, Turkey.

Burhanuddin, U. A., \& Ibrahim, M. (2019). Improving critical thinking skill of preservice chemistry teacher through writing assignment. Journal of Physics: Conference Series, 1307(2019), 012018. doi: 10.1088/1742-6596/1307/1/012018

Butler, G.P. (1990). A study of the effects of utilizing the writing process as an instructional strategy on student thinking skills in ninth-grade biology courses (Doctoral dissertation). Retrieved from https://search. ProQuest. com/pqdtglobal/ results/ 3699BF78271349B 3PQ/1?a ccountid=17396

Çalışkan, H. (2009). Effectiveness on critical thinking skills of inquiry-based learning approach in social studies teaching. Kastamonu Education Journal, 17(1), 57-70. Retrieved from https://www.researchgate.net/publication/303186477

Can, A. (2017). SPPS ile bilimsel araştırma sürecinde nicel veri analizi (5. Baskı). Ankara: Pegem Akademi.

Cantrell, R. J., Fusaro, J. A., \& Dougherty, E. A. (2000). Exploring the effectiveness of journal writing on learning social studies: a comparative study. Reading Psychology, 21(1), 111. doi: $10.1080 / 027027100278310$

Chappell, A. (2006). Using the 'grieving' process and learning journals to evaluate students' responses to problem-based learning in an undergraduate geography curriculum. Journal of Geography in Higher Education, 30(1), 15-31. doi:10.1080/ 03098260500499584 
Cicchino, M. I. (2013). Using game-based learning to foster critical thinking in student discourse (Doctoral Dissertation). Retrieved from ProQuest Dissertations \& Theses Global.

Clark, R. C. (1977). The effects of graphic materials on critical thinking in social studies (Doctoral Dissertation). Retrieved from ProQuest Dissertations \& Theses Global.

Creswell, J.W. (2009). Research design: Qualitative, quantitative and mixed methods approaches (3rd ed.). Thousand Oaks, California: Sage.

Creswell, J. W. (2012). Educational research: Planning, conducting, and evaluating quantitative and qualitative research (4th ed.). Baston: Pearson

Creswell, J.W., \& Plano-Clark, V.L. (2007). Designing and conducting: Mixed methods research. Thousand Oaks, California: Sage.

Daşdemir, İ. (2017). The effect of letter- writing activities for learning purpose students' on academic achievement and critical thinking skills and physics attitudes. Journal of The International Scientific Researches, 2(2), 262-269. doi: 10.21733/ibad.2117

Demirbağ, M. (2011). The effect of multi modal instruction on student's science achievement and writing skills in an argument-based inquiry classroom (Unpublished master's thesis). Kırşehir University, Kırşehir, Turkey.

Emig, J. (1977). Writing as a mode of learning. College Composition and Communication, 28(2), 122-128. Retrieved from https://www.jstor.org/stable/356095

Ennis, R. H. (1993). Critical thinking assessment. Theory into practice, 32(3), 179-186. doi: $10.1080 / 00405849309543594$

Erkan, M. (2008). Effects of writing learning on critical thinking ability in critical thinking and biology education. HAYEF: Journal of Education, 1, 1-10. Retrieved from http:// www.idealonline. com.tr/IdealOnline/ lookAtPublications/paperDetail. Xhtml ?uId $=59878 \&$

Facione, P. A. (1990). Critical thinking: A statement of expert consensus for purposes of educational assessment and instruction. Research findings and recommendations. American Philosophical Association, Newark, Delaware.

Facione, P. A., \& Facione, N. C. (1994). The holistic critical thinking scoring. A tool for developing and evaluating critical thinking. Retrieved from https:// www.insightassessment.com/wp-content/ uplo ads/ia/pdf/rub_hctsr-english.pdf

Flower, L., \& Hayes, J. R. (1981). A cognitive process theory of writing. College Composition and Communication,32(4), 365-387. doi: 10.2307/356600

Frusci, J. (2019). Applying reacting to the past to develop and enhance critical and analytical thinking skills of postsecondary history/social studies students (Doctoral Dissertation). Retrieved from ProQuest Dissertations \& Theses Global.

Giroux, H. A. (1978). Writing and critical thinking in the social studies. Curriculum Inquiry 8(4), 291-310. Retrieved from https://www.jstor.org/stable/1179734?

Green, S. B., \& Salkind, N. J. (2005). Using SPSS for Windows and Macintosh: Analysing and understanding data. Upper Saddle River, New Jersey 07458.

Gupta T., Burke K. A., Mehta A., \& Greenbowe T. J., (2015), Impact of guided-inquiry-based instruction with a writing and reflection emphasis on chemistry students' critical thinking abilities, Journal of Chemical. Education., 92, 32-38. doi:10.1021/ ed500059r

Gürdoğan-Bayır, Ö. (2010). The effects of make use of current events in social studies courses on critical thinking skills of students (Unpublished master's thesis). Anadolu University, Eskişehir, Turkey. 
Hensberry, K. K. R., \& Jacobbe, T. (2012). The effects of Polya's heuristic and diary writing on children's problem solving. Mathematics Education Research Journal, 24, 59-85. doi:10.1007/s13394-012-0034-7

Hobson, E., \& Schafermeyer, K. (1994). "Writing and critical thinking: writing to learn in large classes. American Journal of Pharmacological Education. 58, 423-7. Retrieved from http://citeseerx.ist.psu.edu/viewdoc/download?doi=10.1.1.537.8893\&rep= rep1\& type $=p d f$

Hohenshell. M. L., \& Hand, B. (2006) Writing-to-learn strategies in secondary school cell biology: a mixed method study. International Journal of Science Education, 28(2-3), 261-289. doi: 10.1080/09500690500336965

Hooey, C. A., \& Bailey, T. J. (2005). Journal writing and the development of spatial thinking skills, Journal of Geography, 104(6), 257-261. doi: 10.1080/00221340508978647

İbrahimoğlu, Z., \& Öztürk, C. (2013). The effects of using case study technique at the 6th grade social studies course on students' academic achievement attitudes towards the course, and critical thinking skills. Journal of Uludağ University Faculty of Education, 26(2), 523-547. Retrieved from https://dergipark. org.tr/tr/ pub/uefad/issue/16698/173592

Karaatlı, M. (2017). Verilerin düzenlenmesi ve gösterimi. In Ş. Kalaycı (Ed.), SPSS uygulamalı çok değişkenli istatistik teknikleri (8. baskl, ss. 3-47). Ankara: Dinamik Akademi

Keys, C. W., Hand, B., Prain, V., \& Collins, S. (1999). Using the science writing heuristic as a tool for learning from laboratory investigations in secondary science. Journal of Research in Science Teaching, 36(10), 1065-1084. doi: 10.1002/(SICI)1098 2736 (199912)36:10<1065: AID-TEA2>3.0.CO;2-I

Kingir, S. (2013). Using non-traditional writing as a tool in learning chemistry. Eurasia Journal of Mathematics, Science \& Technology Education, 9(2), 101-114. doi: 10. 129 73/ eurasia.2013. 922a

Knipper, K. J., \& Duggan, T. J. (2006). Writing to learn across the curriculum: tools for comprehension in content area classes. The Reading Teacher, 59(5), 462-470. doi: 10.1598/RT.59.5.5

Kökdemir, D. (2003). Decision making and problem solving in cases of uncertainty (Unpublished doctoral dissertation). Ankara University, Ankara, Turkey.

Köksal, A. P. (2019). The effect of writing activities for learning purposes on the academic achievements of fifth grade students about electricity, permanence and their attitudes towards science lesson (Unpublished master's thesis). Atatürk University, Erzurum, Turkey.

Köseoğlu, M. (2009). Effects of cartoon use on critical thinking in social studies (Unpublished master's thesis). Gaziosmanpaşa University, Tokat, Turkey.

Külekçi, Z. (2018). Examination of the 8th grade students' academical success and their behaviors for the structure and properties of matter as writing story (Unpublished master's thesis). Giresun University, Giresun, Turkey.

Lin, L., Widdall, C., \& Ward, L. (2014). Improving critical thinking with interactive mobile tools and apps. Social Studies and the Young Learner, 26(4), 10-14. Retrieved from https://www.socialstudies.org/publications/ssyl/marchapril2014/improving_critic al_thinking_with_interactive_ mobile_tools_and_apps

McMillan, J. H. \& Schumacher, S. (2014). Research in education: Evidence-based inquiry (7th ed.). London: Pearson.

Meral, E. (2018). The effects of the argumentation-based science learning approach on students' academic achievement critical thinking dispositions and argument 
development skills (Unpublished doctoral dissertation). Atatürk University, Erzurum, Turkey.

Miles, M. B., \& Huberman, A. M. (2016). Nitel veri analizi. S. Akbaba, A. A. Ersoy, (Cev. Ed.). Ankara: Pegem.

Ministry of National Education (MoNE), (2018). Sosyal bilgiler öğretim programı (ilkokul, ortaokul 4,5,6,7). Retrieved from http://mufred at.meb. gov.tr/ Program Detay .aspx ?PID=354

National Council for The Social Studies, (NCSS), (1994). National curriculum standards for social studies: Introduction. Retrieved from https:// www.socialstudies.org/ standards/ introduction

Nejmaoui, N. (2019). Improving EFL learners' critical thinking skills in argumentative writing. English Language Teaching, 12(1), 98-109. doi: 10.5539/elt.v12n1p98

Noel, K. A. (1996). Writing as a tool for learning in a grade seven social studies classroom (Doctoral Dissertation). Retrieved from https:// search.proquest.com/pqdtglobal/ results/D0EC3950B 919480BPQ/ ?accountid= 7396

Nurnberg, D. (2017). Writing-to-Learn in High-School Chemistry: The Effects of Using the Science Writing Heuristic to Increase Scientific Literacy (Doctoral Dissertation). Retrieved from ProQuest Dissertations \& Theses Global.

Öz, M. (2015). Effects of the using multi modal representations within writing to learn activities on $5^{\text {th }}$ grade students" learning, scientific process skills critically thinking natural \& applied sciences attitudes (Unpublished master's thesis). Kastamonu University, Kastamonu, Turkey.

Özden, Y. (2014). Öğrenme ve öğretme (12. Baskı). Ankara: Pegem Akademi.

Öztürk, C. (2015). Sosyal bilgiler: toplumsal yaşama disiplinlerarası bir bakış. C. Öztürk (Ed.) Sosyal bilgiler öğretimi demokratik vatandaşlık eğitimi (4. baskı, ss. 2-31). Ankara: Pegem Akademi.

Pallant, J. (2005). SPSS survival manual: A step by guide to data analysis using spss for windows (2nd ed.). National Library of Australia.

Pinar, E. (2019). The effect of diary among writing to learn activities on the success and science attitude in fourth grade science lesson (Unpublished master's thesis). Atatürk University, Erzurum, Turkey.

Poock, J. R., Burke, K. A., Greenbowe, T. J., \& Hand, B. M. (2007). Using the science writing heuristic in the general chemistry laboratory to improve students' academic performance. Journal of Chemical Education, 84(8), 1371-1379. doi: 10.1021/ ed084p1371

Putti, A. (2011). High school students' attitudes and beliefs on using the science writing heuristic in an advanced placement chemistry class. Journal of Chemical Education, 88(4), 516-521. doi: 10.1021/ed100135w

Quitadamo, L. J., \& Kurtz, M. J. (2007). Learning to improve: Using writing to increase critical thinking performance in general education biology. Life Sciences Education, 6(2), 140154. doi: $10.1187 /$ cbe.06-11-0203

Reilly, E. M. (2007). Writing to learn mathematics: A mixed method study Retrieved from ProQuest Dissertations \& Theses Global.

Rivard, L. P. (1994). A review of writing to learn in science: Implications for practice and research. Journal of Research in Science Teaching, 31(9). 969-983. doi: 10.1002/ tea. 3660310910

Ruggiero, V. R. (2017). Eleștirel düşünme için bir rehber. (Ç. Dedeoğlu, çev.). İstanbul: Alfa. 
Şahinel S. (2015). Eleştirel düşünme. In Ö. Demirel (Ed.) Eğitimde yeni yönelimler (6. baskı, ss. 123-136). Ankara: Pegem.

Shepherd, N. G. (1998). The Probe Method: A problem-based learning model's effect on critical thinking skills of fourth and fifth grade social studies students. Retrieved from ProQuest Dissertations \& Theses Global.

Sielaff, C. K., \& Washburn, E. K. (2015). The PEA strategy: One teacher's approach to integrating writing in the social studies classroom. The Social Studies, 106(4), 178185. doi: 10.1080/00377996.2015.1043616

Sinaga, P., \& Feranie, S. (2017). Enhancing critical thinking skills and writing skills through the variation in non-traditional writing task. International Journal of Instruction, 10(2), 69-84. doi: 10.12973/iji.2017.1025a

Stephenson, N. S., \& Sadler-McKnight, N. P. (2016). Developing critical thinking skills using the Science Writing Heuristic in the chemistry laboratory. Chemistry Education Research and Practice, 17(1), 72-79. doi: 10.1039/c5rp00102a

Tabachnick, B. G., \& Fidell, L. S. (2015). Çok değiş̧kenli istatistiklerin kullanımı (M. Baloğlu, çev. ed.). Ankara: Nobel.

Tarchichi, R. M. (2016). The impact of mathematics, science and language arts writing to learn strategies on the culture of learning in primary and secondary students (Doctoral Dissertation). Retrieved from ProQuest Dissertations \& Theses Global.

Tynjala, P. (1998). Writing as a tool for constructive learning: students' learning experiences during an experiment. Higher Education, 36(2), 209-23. Retrieved from https://link.springer.com/article/ 10.1023/A:1003260402036

Ünlü, B. (2018). The effect of digital stories based social studies courses on students' achievement, locus of control and critical thinking skills (Unpublished master's thesis). Recep Tayyip Erdoğan University, Rize, Turkey.

Uzoğlu, M. (2014). The effects of diverse writing activities in learning on academic achievement, critical thinking skills, and laboratory attitudes of prospective science teachers: Giresun faculty of education sample. The Black Sea Journal of Social Sciences, 6, 195-209. Retrieved from https://www.academia.edu/11041343/

VanOrden, N. (1987). “Critical-thinking writing assignments in general chemistry. Journal of Chemical Education, 64(6), 506-507. doi: 10.1021/ed064p506

Walp, D. (2013). Reflective writing in a high-ability middle school social studies classroom (MSc thesis). Retrieved from https://www.moravian.edu/education/research/medthesis $/ 2013$

Yasul, A. F. (2019). The effect of writing to learn activities used in social studies course on academic achievement, retention in learning and attitude towards writing (Unpublished doctoral dissertation). Atatürk University, Erzurum, Turkey.

Yllmaz, N. (2017). Change of using skills of modals representation of secondary school students (Unpublished master's thesis). Giresun University, Giresun Turkey.

Yücel, A. G., \& Köçer, M. (2019). The effect of controversial issues on the development of social studies teacher candidates' critical thinking levels. Journal of Social Sciences of Mus Alparslan University, 7(3), 129-139. doi: 10.18506/anemon.468137

Zarrillo, J. J. (2016). Sosyal bilgiler öğretimi ilkeler ve uygulamalar. (B. Tay \& S. B. Demir, çev. ed.). Ankara: Anı.

Zhang, L. F. (2003). Contributions of thinking styles to critical thinking dispositions. The Journal of Psychology, 137(6), 517-544. doi: 10.1080/00223980309600633 


\section{Biographical Statements}

Fatih KAYAALP is doctor at the Department of Turkish and Social Sciences Education in Ereğli Faculty of Education at Zonguldak Bülent Ecevit University. He focuses on social studies teaching, citizenship education, writing- to- learn and technology in social sciences.

Elif MERAL is assistant professor doctor at the Department of Turkish and Social Sciences Education in Kazım Karabekir Faculty of Education at Atatürk University. She focuses on social studies teaching, argumentation, technology-assisted teaching, augmented reality, writing- to- learn and technology in social sciences.

Ufuk ŞIMŞEK is professor doctor at the Department of Turkish and Social Sciences Education in Kazım Karabekir Faculty of Education at Atatürk University. He focuses on social studies teaching, cooperative learning, seven principles in education, writing- tolearn.

İbrahim Fevzi ŞAHIN is professor doctor at the Department of Turkish and Social Sciences Education in Kazım Karabekir Faculty of Education at Atatürk University. He focus on human geography, geography education, social studies teaching, argumentation and technology in social sciences. 